This is a non-peer reviewed preprint: version 2 of a manuscript submitted to Global Biogeochemical Cycles, which has been modified according to reviewers' comments and is currently in review again at Global Biogeochemical Cycles.

\title{
1 Dark carbon fixation in the Arabian Sea oxygen minimum zone contributes to 2 sedimentary organic carbon (SOM)
}

\section{Sabine K. Lengger ${ }^{1,2,3^{*}}$, Darci Rush ${ }^{3}$, Jan Peter Mayser ${ }^{2}$, Jerome Blewett ${ }^{2}$, Rachel} Schwartz-Narbonne ${ }^{4}$, Helen M. Talbot ${ }^{4, \dagger}$, Jack J. Middelburg ${ }^{5}$, Mike S.M. Jetten ${ }^{6}$, Stefan Schouten $^{3,5}$, Jaap S. Sinninghe Damsté ${ }^{3,5}$ and Richard D. Pancost ${ }^{2}$

${ }^{1}$ Biogeochemistry Research Centre, School of Geography, Earth and Environmental Science, University of Plymouth, PL48AA, Plymouth, United Kingdom.

${ }^{2}$ Organic Geochemistry Unit, School of Chemistry, University of Bristol, BS81TS, Bristol, United Kingdom.

${ }^{3}$ NIOZ Royal Netherlands Institute for Sea Research, Dept. of Marine Microbiology and Biogeochemistry, and Utrecht University,1797SZ, Texel, The Netherlands.

${ }^{4}$ School of Natural and Environmental Sciences, Newcastle University, Drummond Building, NE1 7RU, Newcastle-upon-Tyne, United Kingdom.

${ }^{5}$ Department of Earth Sciences, Faculty of Geosciences, Utrecht University, 3508 TA, Utrecht, The Netherlands.

${ }^{6}$ Department of Microbiology, IWWR, Radboud University Nijmegen, 6525 XZ, Nijmegen, The Netherlands

* corresponding author: Sabine Lengger (sabine.lengger@plymouth.ac.uk)

$\dagger$ present address: BioArCh, Environment Building, University of York, YO10 5DD, Heslington, United Kingdom.

\section{Key Points:}

- One fifth of organic matter on Arabian Sea seafloor could stem from bacterial carbon fixation in the oxygen minimum zone

- Evaluation of past anoxic events needs to take chemoautotrophic contribution into account in isotope balances

- Biogeochemical models ignoring dark carbon fixation could highly underestimate oxygen demand and thus expansion of oxygen minimum zones 
This is a non-peer reviewed preprint: version 2 of a manuscript submitted to Global Biogeochemical Cycles, which has been modified according to reviewers' comments and is currently in review again at Global Biogeochemical Cycles.

\begin{abstract}
In response to rising $\mathrm{CO}_{2}$ concentrations and increasing global sea surface temperatures, oxygen minimum zones (OMZ), or "dead zones", are expected to expand. OMZs are fueled by high primary productivity, resulting in enhanced biological oxygen demand at depth, subsequent oxygen depletion, and attenuation of remineralization. This results in the deposition of organic carbon-rich sediments. Carbon drawdown is estimated by biogeochemical models; however, a major process is ignored: carbon fixation in the mid- and lower water column. Here, we show that chemoautotrophic carbon fixation is important in the Arabian Sea OMZ; and manifests in a ${ }^{13} \mathrm{C}$-depleted signature of sedimentary organic carbon. We determined the $\delta^{13} \mathrm{C}$ values of SOM deposited in close spatial proximity but over a steep bottom-water oxygen gradient, and the $\delta^{13} \mathrm{C}$ composition of biomarkers of chemoautotrophic bacteria capable of anaerobic ammonia oxidation (anammox). Isotope mixing models show that detritus from anammox bacteria or other chemoautotrophs likely forms a substantial part of the organic matter deposited within the Arabian Sea OMZ ( 17\%), implying that the contribution of chemoautotrophs to settling organic matter is exported to the sediment. This has implications for the evaluation of past, and future, OMZs: biogeochemical models that operate on the assumption that all sinking organic matter is photosynthetically derived, without new addition of carbon, could significantly underestimate the extent of remineralization. Oxygen demand in oxygen minimum zones could thus be higher than projections suggest, leading to a more intense expansion of OMZs than expected.
\end{abstract}

\title{
Plain Language Summary
}

Oxygen minimum zones are areas in the ocean in which algae produce large amounts of organic material. When this sinks towards the seafloor, all oxygen at depth is used up. This results in vast "dead zones" where almost no oxygen is available to sustain life. With global warming, and increased nutrients from rivers, dead zones are forecast to expand. Computer models can calculate this, by considering algal production, and the amount of material delivered to the seafloor. However, these models often ignore a major process: anaerobic bacteria in the deeper water column, that can live at the edge or in the middle of these dead zones, which can also produce organic material from the dissolved $\mathrm{CO}_{2}$. In this study, we used the fact that these bacteria add a distinct signature to the organic material, to show that one fifth of the organic matter on the seafloor could stem from bacteria living in these dead zones. Thus, models that have missed out on considering this contribution could have underestimated the extent of oxygen depletion we are to expect in a future, warming world. A more intense expansion of dead zones than expected could have severe ecological, economical (fisheries), and climatic consequences. 
This is a non-peer reviewed preprint: version 2 of a manuscript submitted to Global Biogeochemical Cycles, which has been modified according to reviewers' comments and is currently in review again at Global Biogeochemical Cycles.

\section{Introduction}

Marine primary production fixes $50 \mathrm{Pg}$ carbon per year, of which only about $1 \%$ is buried in sediments (Dunne et al., 2007; Middelburg, 2011). The majority of organic carbon derived from the photic zone is remineralised during sedimentation, fueling heterotrophic bacterial activity in the water column (Keil et al., 2016). In marginal settings and OMZs, marine primary production in the photic zone can be significantly higher than in other settings. Organic carbon (OC) sedimentary accumulation rates within an OMZ can be in the range of tens to hundreds of mg C cm${ }^{-2} \mathrm{y}^{-1}$ (Hartnett et al., 1998; Hedges and Keil, 1995) higher than observed in other parts of the ocean. These high accumulation rates are most commonly attributed to attenuation in remineralization rates within the $\mathrm{OMZ}$, and low bottom-water oxygenation, which results in decreased biodegradability of polymeric and matrix-protected substances (Burdige, 2007).

As a consequence of increasing atmospheric $\mathrm{CO}_{2}$ concentrations and, consequently, temperature, oceanic OMZs are forecast to expand in a fashion similar to the past (Breitburg et al., 2018; Queste et al., 2018; Schmidtko et al., 2017; Shaffer et al., 2009; Stramma et al., 2010). Whilst the expansion of OMZs will result in widespread habitat loss of marine life and could cause an increase in emissions of greenhouse gases such as $\mathrm{N}_{2} \mathrm{O}$ and $\mathrm{CH}_{4}$, it could also act as a long-term negative feedback on global warming via the enhanced drawdown and storage of organic carbon in sediments.

The biogeochemical system in subsurface waters, where light does not penetrate, has recently emerged to be substantially more complex - and possibly more important for the global carbon cycle - than previously assumed. In particular, dark water-column microbial activity is higher than what can be accounted for by heterotrophs (Herndl and Reinthaler, 2013), suggesting an important role for chemoautotrophy, i.e. fixation of dissolved inorganic carbon (DIC). It has been suggested to contribute substantially to the global carbon budget, with estimates ranging from 0.11 to $1.1 \mathrm{Pg} \mathrm{C} \mathrm{y}^{-1}$, equating to ca. $2 \%$ of total estimated yearly marine primary production (Middelburg, 2011; Reinthaler et al., 2010). The predominant chemoautotrophic process in the oxic, dark, pelagic ocean is thought to be nitrification (Middelburg, 2011; Pachiadaki et al., 2017). When oxygen is limited, nitrification still occurs, but other chemoautotrophic processes dominate, such as anaerobic oxidation of ammonia and sulfide oxidation (Ulloa et al., 2012; Wright et al., 2012).

Under hypoxic conditions, such as in the water column of OMZs, both archaeal (aerobic) and anaerobic oxidation of ammonia are thought to dominate dark inorganic carbon fixation processes (Lam and Kuypers, 2010; Pitcher et al., 2011). Here, nitrite accumulates, and other anaerobic autotrophic processes such as sulfide oxidation and methanogenesis are suppressed, most likely due to the abundance of nitrate and ammonia (Canfield, 2006; Ulloa et al., 2012).

Of the inorganic carbon converted to organic matter within the OMZ, only a negligible fraction is presumably transported to the sediments and preserved, as this newly produced material is regarded as more labile than the sinking OC derived from the photic zone (Cowie and Hedges, 1992; Keil et al., 1994; Middelburg, 1989). Dark carbon fixation rates are challenging to quantify: they have been determined experimentally (Reinthaler et al., 2010; Taylor et al., 2001), or have been estimated from the reaction stoichiometry of respiration based on Redfield organic matter and growth yields of nitrifiers (Middelburg, 2011; Wuchter et al., 2006). In OMZs, such as the Peruvian margin (Lam et al., 2009), the Arabian Sea (Jensen et al., 2011), or the sulfidic Black Sea (Lam et al., 2007), the activity of some chemoautotrophs was determined via ${ }^{15} \mathrm{~N}-$ 
This is a non-peer reviewed preprint: version 2 of a manuscript submitted to Global Biogeochemical Cycles, which has been modified according to reviewers' comments and is currently in review again at Global Biogeochemical Cycles.

labelling, and formation of the products of their biogeochemical reactions. However, incubation methods may suffer from bias, because in situ conditions such as pressure are difficult to maintain.

However, carbon from within anoxic waters has been observed in some settings to contribute to the particulate OC flux: for example, in eutrophic lakes (Hollander and Smith, 2001) and anoxic fjords (van Breugel et al., 2005b). Furthermore, discrepancies between modelled and observed organic carbon fluxes suggest that dark carbon fixation in anoxic marine settings significantly contributes to sinking material (Keil et al., 2016; Taylor et al., 2001).

One way to constrain this input into sedimentary organic matter is to use isotope mixing models. Photosynthetically fixed carbon generally has stable carbon isotopic compositions of ca -19 to $-21 \%$ due to Rubisco fixation. However, chemoautotrophs dwelling in OMZs typically have a lower $\delta^{13} \mathrm{C}$ values. This is the result of multiple factors: they either use ${ }^{13} \mathrm{C}$-depleted $\mathrm{CO}_{2}$ generated by remineralization, have larger fractionation factors due to the higher abundance of $\mathrm{CO}_{2}$ at depth (Freeman et al., 1994), or use carbon fixation pathways such as the acetyl coenzyme A pathway, which results in ${ }^{13} \mathrm{C}$-depleted biomass (Hayes, 2001). This characteristic chemoautotrophic isotopic signature in the organic carbon could allow us to quantify the contribution of dark carbon fixation to sedimentary organic matter.

Here, we investigated the $\delta^{13} \mathrm{C}$ value of sedimentary organic matter of surface sediments deposited within the OMZ of the Arabian Sea and employed a simple isotope mixing model to investigate the extent of input from $\mathrm{OMZ}$ carbon fixation into sedimentary organic matter. As the major process in the Arabian Sea OMZ known to produce isotopically light biomass is anaerobic oxidation of ammonia (anammox; Ulloa et al., 2012; Villanueva et al., 2014), in order to determine the isotopic signature of this pathway, we developed and applied a method to determine the $\delta^{13} \mathrm{C}$ values of a novel biomarker, bacteriohopanetetrol stereoisomer (BHT'), which has been found to be unique to anammox bacteria in the marine environment in culture

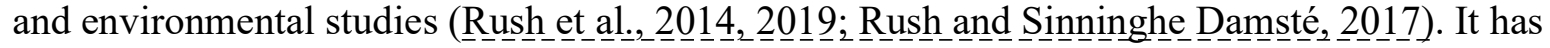

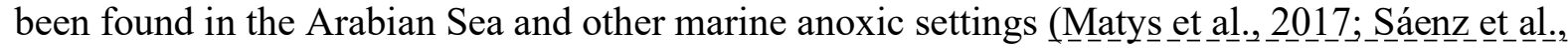
2011). We also used stable isotope probing experiments to exclude sedimentary anammox as an important contributor to this process. This allowed us to investigate the contribution of these dark carbon fixers to sedimentary organic carbon.

\section{$2 \quad$ Materials and Methods}

\subsection{Sediment sampling and stable isotope probing incubations}

Sediments were collected with multicore devices on the R/V Pelagia in the Northern Arabian Sea in January 2009 during the PASOM cruise 64PE301 along the Murray Ridge (Fig. 1f), which protrudes into the core of the OMZ. Two cores, one each from P900 (885 m water depth) and P1800 (1786 m water depth), hereinafter referred to as anoxic and oxic, respectively, were incubated on board as described by Pozzato et al. (2013 a, b). In brief, particulate or dissolved organic matter from the diatom Thalassiosira pseudonana containing 20 and $18 \%{ }^{13} \mathrm{C}$, respectively, were added to the tops of core tubes of $10 \mathrm{~cm}$ internal diameter. Between 2 and $6 \%$ of the added carbon was respired, resulting in a highly enriched ${ }^{13} \mathrm{C}_{\mathrm{DIC}}$ pool, enabling the tracing of autotrophic processes in addition to heterotrophic processes. 
This is a non-peer reviewed preprint: version 2 of a manuscript submitted to Global Biogeochemical Cycles, which has been modified according to reviewers' comments and is currently in review again at Global Biogeochemical Cycles.
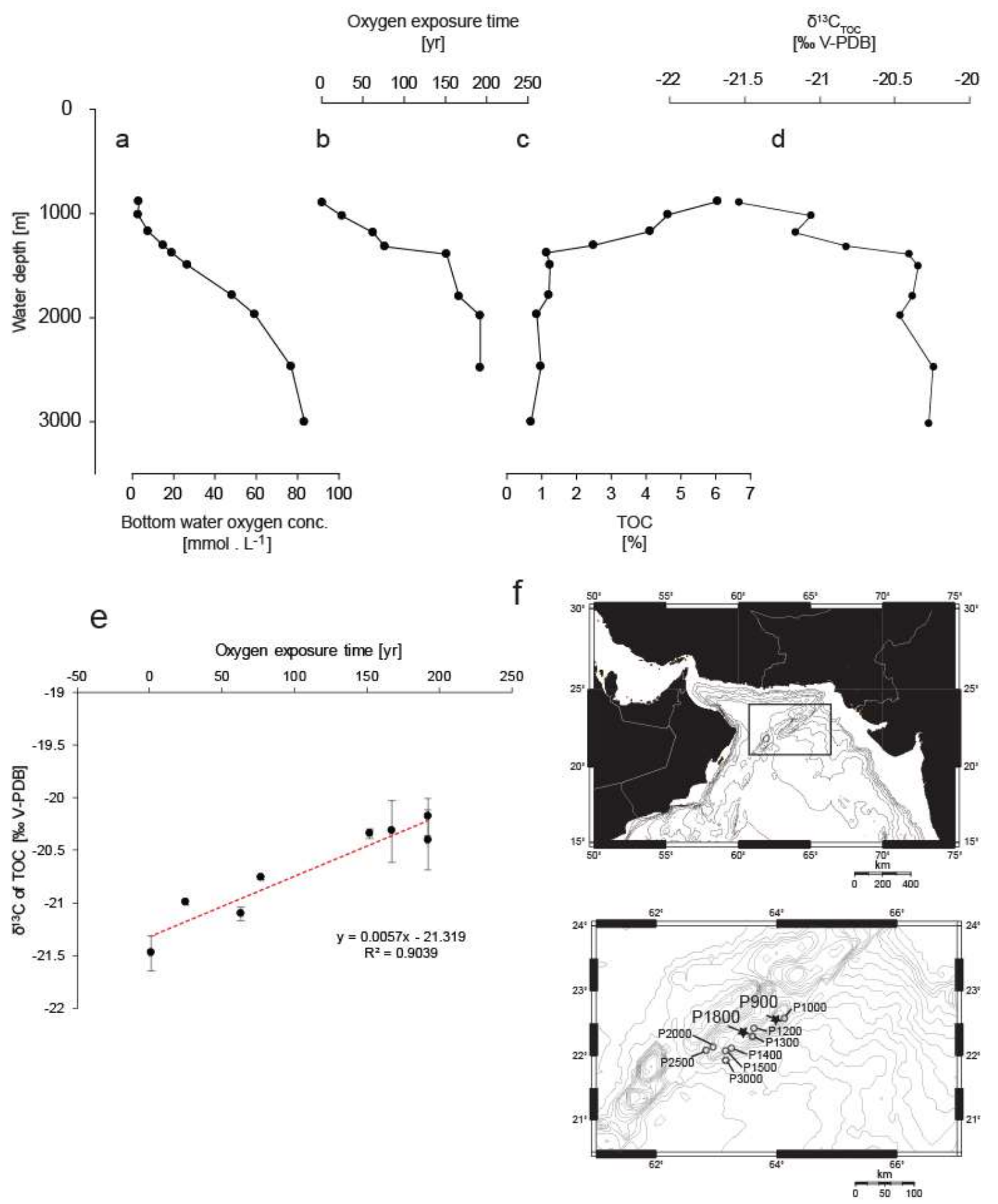

Figure 1. Arabian Sea depth gradients. Shown are $\delta^{13} \mathrm{C}_{\text {org }}$ and $\%$ TOC values of core top sediments, and bottom water oxygenation plotted with depth (a-d), all but $\delta^{13} \mathrm{C}_{\text {org }}$ replotted from Lengger et al. (2014), a scatter plot of oxygen exposure time versus $\delta^{13} \mathrm{C}_{\text {org }}$ in Arabian Sea core tops along Murray Ridge (e), and a map of the sampling stations with the two main stations used for BHT analysis used here indicated with a star (f). 
This is a non-peer reviewed preprint: version 2 of a manuscript submitted to Global Biogeochemical Cycles, which has been modified according to reviewers' comments and is currently in review again at Global Biogeochemical Cycles.

Eight cores are discussed here; these were incubated under oxic or suboxic conditions for 7 days $\left(125 \mu \mathrm{M}, 6 \mu \mathrm{M} \mathrm{O}_{2}\right.$, respectively; Table 1). At the end of incubation, cores were sliced in the intervals $0-2,2-4$, and $4-10 \mathrm{~cm}$ depth. They were then frozen and freeze dried for the isotopic analysis of the bacteriohopanepolyol lipids (BHPs), including bacteriohopanetetrol (BHT) and its stereoisomer and biomarker for anammox bacteria, BHT'. Both biomarkers have been studied previously in the Arabian Sea water column and sediments (Jaeschke et al._.2009; Sáenz_etal...2011). Furthermore, cores from 8 stations between 900 and $3000 \mathrm{~m}$ water depth were also collected, as described by Lengger et al. $(2014,2012 \mathrm{~b})$. The top $0-0.5 \mathrm{~cm}$ were used for total organic carbon (TOC) and ${ }^{13} \mathrm{C}$ of organic carbon analysis. For the core from P900 $(32 \mathrm{~cm}$ length), all depths were analysed in $0.5 \mathrm{~cm}-4 \mathrm{~cm}$ resolution (Lengger et al., 2012b).

\subsection{Anammox enrichment cultures}

To determine the $\delta^{13} \mathrm{C}$ values for the two bacteriohopanetetrols in anammox bacteria (BHT and BHT', the latter being unique to anammox in the marine environment), an enrichment culture of ' $\mathrm{Ca}$. Scalindua profunda' was analysed. It was grown in a sequencing batch reactor as described by van de Vossenberg et al. (2008). Analysis of this enrichment culture that showed ' $\mathrm{Ca}$. S. profunda' comprised about $80 \%$ of the cells, while other bacteria belonging to the phyla Bacteriodetes (including Flavobacteriaceae) and Proteobacteria (including Alphaproteobacteria) accounted for the majority of the remaining populations (van de Vossenberg et al., 2008, 2013).

\subsection{Extraction and purification}

The freeze-dried subsamples of the unamended and incubated cores were ground, and the homogenised sediments and the culture were extracted by a modified Bligh-Dyer extraction method (Lengger et al., 2012a). Briefly, they were extracted ultrasonically three times in a mixture of methanol/dichloromethane (DCM)/phosphate buffer (2:1:0.8, v:v:v) and centrifuged, and the solvent phases were combined. The solvent ratio was then adjusted to 1:1:0.9, v:v:v to separate the DCM phase. Liquid extraction was repeated two more times, the DCM fractions were combined, the solvent was evaporated and the larger particles were filtered out over glass wool. The extraction procedure was performed on the enrichment culture material and repeated on the sediment for analysis of BHPs. An aliquot of the extract was subjected to column chromatography using 5\% aminopropyl solid phase extraction (SPE), eluting with hexane, DCM, and $\mathrm{MeOH}$, which contained BHPs. For analysis by chromatographic techniques, the extract was derivatised in $0.5 \mathrm{~mL}$ of a $1: 1(\mathrm{v}: \mathrm{v})$ mixture of acetic anhydride and pyridine at $50^{\circ} \mathrm{C}$ for $1 \mathrm{~h}$, then at room temperature overnight in the case of HPLC-MS analysis. Solvent was dried under a stream of $\mathrm{N}_{2}$ on a $50^{\circ} \mathrm{C}$ heating block.

\subsection{Instrumental techniques}

\subsubsection{High temperature gas chromatography coupled to flame ionization detection (HTGC-FID)}

GC analysis of acetylated BHPs was done using a HP-5890 Series II GC equipped with a flame ionization detector was fitted with a $0.25 \mathrm{~mm}$ x $0.1 \mu \mathrm{m}$ VF5-ht capillary column (CP9045, CP9046, Agilent Technologies UK Ltd., Stockport, UK) of 30 m length (Lengger et al., 2018). An on-column injector was used. To the $30 \mathrm{~m}$ column, $1 \mathrm{~m}$ of a $0.25 \mathrm{~mm}$ HT-deactivated silica tubing was attached as a guard column (Zebron Z-Guard, 7CG-G000-00GH0, Phenomenex, Macclesfield, UK). Analysis of bacteriohopanepolyols employed a constant flow of $2 \mathrm{ml} / \mathrm{min} \mathrm{He}$ and a temperature ramp from $70^{\circ} \mathrm{C}(1 \mathrm{~min}$ hold $)$ to $400^{\circ} \mathrm{C}$ at $7^{\circ} \mathrm{C} \mathrm{min}^{-1}(1 \mathrm{~min}$ hold $)$. 
This is a non-peer reviewed preprint: version 2 of a manuscript submitted to Global Biogeochemical Cycles, which has been modified according to reviewers' comments and is currently in review again at Global Biogeochemical Cycles.

2.4.2. High temperature gas chromatography coupled to mass spectrometric detection (HTGCMS)

Analysis of acetylated BHPs, using HTGC-MS was performed using a Thermo Scientific Trace 1300 gas chromatograph coupled with an ISQ single quadrupole mass spectrometer. Diluted samples were introduced using a PTV injector in splitless mode onto a $0.53 \mathrm{~mm}$ fused silica pre-column connected to a $30 \mathrm{~m} \times 0.25 \mathrm{~mm}$ i.d. fused-silica capillary column coated with dimethyl polysiloxane stationary phase (ZB-5HT; film thickness, $0.1 \mu \mathrm{m}$; 7HG-G015-02, Phenomenex, Macclesfield, UK). The initial injection port temperature was $70^{\circ} \mathrm{C}$ with an evaporation phase of $0.05 \mathrm{~min}$, followed by a transfer phase from $70{ }^{\circ} \mathrm{C}$ to $400{ }^{\circ} \mathrm{C}$ at $0.2{ }^{\circ} \mathrm{C} \mathrm{s}^{-1}$. The oven temperature was held isothermally for $1 \mathrm{~min}$ at $70^{\circ} \mathrm{C}$, increased at a rate of $7{ }^{\circ} \mathrm{C} \mathrm{min}{ }^{-1}$ to $400{ }^{\circ} \mathrm{C}$ and held at $400^{\circ} \mathrm{C}$ for $10 \mathrm{~min}$. Helium was used as a carrier gas and maintained at a constant flow of $2.5 \mathrm{ml} \mathrm{min}^{-1}$. The mass spectrometer was operated in the electron ionization (EI) mode $(70 \mathrm{eV})$ with a $\mathrm{GC}$ interface temperature of $400^{\circ} \mathrm{C}$ and a source temperature of $340{ }^{\circ} \mathrm{C}$. The emission current was $50 \mu \mathrm{A}$ and the mass spectrometry set to acquire in the range of $m / z$ 50-950 Daltons with $0.5 \mathrm{~s}$ dwell time. Data acquisition and processing were carried out using the Thermo XCalibur software (version 3.0.63). Due to the lack of authentic standards for BHT and BHT', only relative and not absolute values are reported, assuming similar ionization energies.

\subsubsection{High temperature gas chromatography coupled to isotope ratio mass spectrometry (HTGC-} IRMS)

The stable carbon isotopic composition $\left(\delta^{13} \mathrm{C}\right)$ of BHPs were determined using HTGCisotope ratio mass spectrometry. To this end, an Elementar visION IRMS with GC5 interface (Elementar UK Ltd., Cheadle, UK), and an Agilent 7890B GC were modified in-house and allowed us to achieve column temperatures of up to $400{ }^{\circ} \mathrm{C}$, which resulted in baseline resolution of BHT and BHT' (Fig. 2). $1 \mu \mathrm{l}$ of the derivatized samples dissolved in ethyl acetate were injected on a cool-on-column injector, into a Zebron Z-Guard Hi-Temp Guard Column (1 m x $0.25 \mathrm{~mm}$, Zebron Z-Guard, 7CG-G000-00GH0, Phenomenex, Macclesfield, UK) and separated on a Zebron ZB-5HT analytical column (30 m x $0.25 \mathrm{~mm}$ x $0.1 \mu \mathrm{m}$, Phenomenex Ltd., Macclesfield, UK). He was used as a carrier gas at a flow rate of $1.5 \mathrm{ml} \mathrm{min}^{-1}$ and the oven was programmed as follows: $1 \mathrm{~min}$ hold at $70{ }^{\circ} \mathrm{C}$, increase by $7{ }^{\circ} \mathrm{C} \mathrm{min}-1$ to $350{ }^{\circ} \mathrm{C}(10 \mathrm{~min}$ hold $)$. Organic compounds were combusted to $\mathrm{CO}_{2}$ in a $0.7 \mathrm{~mm}$ ID quartz tube with $\mathrm{CuO}$ pellets at $850^{\circ} \mathrm{C}$. Instrumentation performance was monitored using an n-alkane standard (B3, A. Schimmelmann, Indiana University, Bloomington, IN, USA; RMS $0.4 \%$ ), and results were calibrated using an in-house mixture of five fatty acid methyl esters, which was injected between every six sample analyses and analyzed using a He flow of $1 \mathrm{ml} \mathrm{min}^{-1}$, with a slightly different temperature program (injection at $50{ }^{\circ} \mathrm{C}$ held for $1 \mathrm{~min}$ followed by an increase of $10^{\circ} \mathrm{C} \mathrm{min}^{-1}$ to $300^{\circ} \mathrm{C}$ and a 10 min hold). This is the first time baseline resolution between BHT and BHT' has been achieved on a GC-IRMS, which allows the direct determination of the isotopic composition of both BHT and BHT' in sediment samples (Fig. 2). The isotopic composition of the acetyl group used to derivatise the BHT and BHT' was determined by acetylation of myo-inositol, and then subtracted from the values of BHT and BHT' in a mass balance correction (Angelis et al., 2012), as authentic standards for BHT or BHT' were not available. 
This is a non-peer reviewed preprint: version 2 of a manuscript submitted to Global Biogeochemical Cycles, which has been modified according to reviewers' comments and is currently in review again at Global Biogeochemical Cycles.

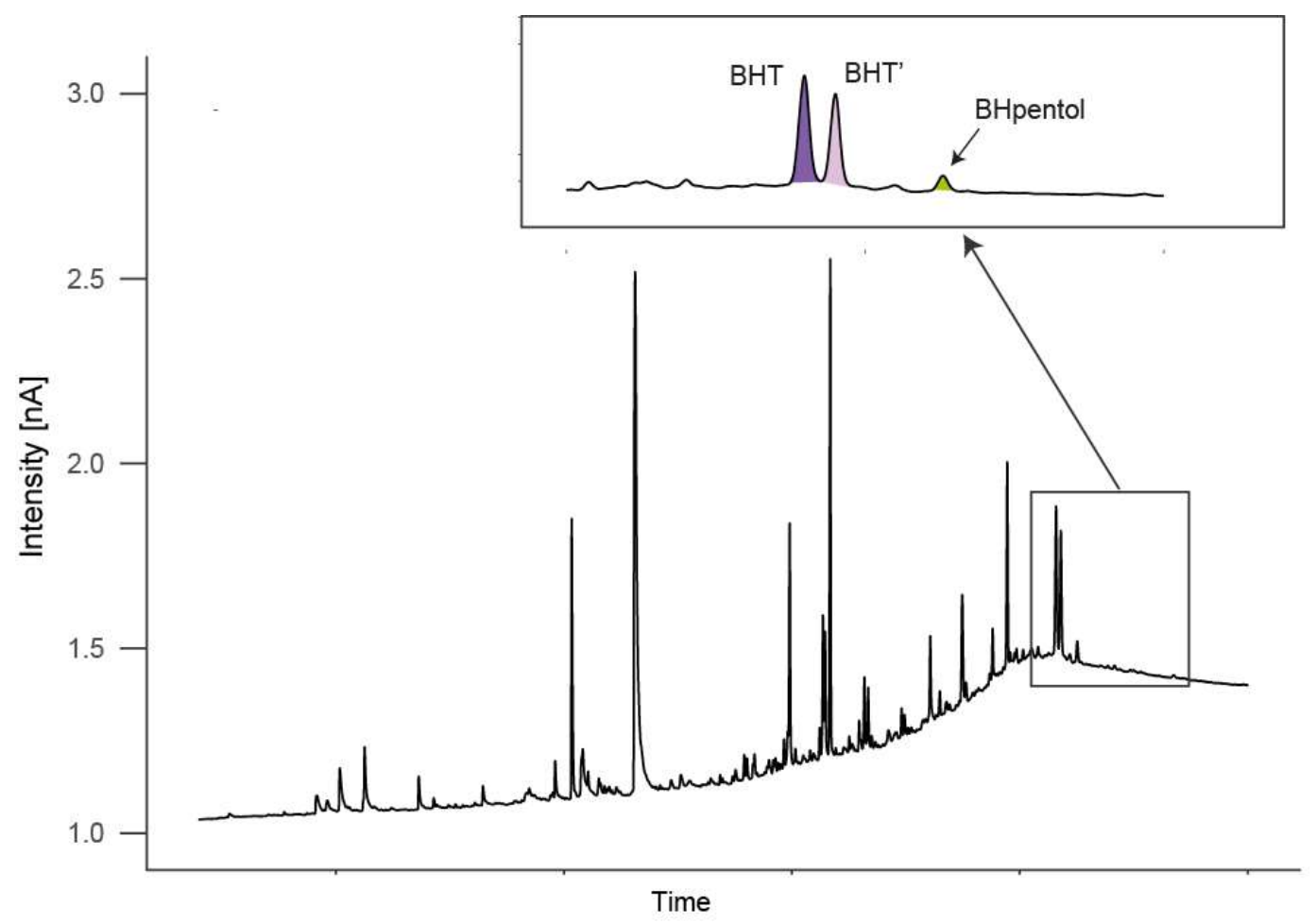

Figure 2. HTGC-IRMS chromatogram showing baseline separation between BHT, BHT', and BHpentol.

2.4.4. High performance liquid chromatography coupled to positive ion atmospheric pressure chemical ionization mass spectrometry (HPLC/APCI-MS)

To verify the GC-derived assignments, an aliquot of the acetylated BHP samples was dissolved in MeOH:propan-2-ol (3:2; v:v) and filtered on $0.2 \mu \mathrm{m}$ PTFE filters. BHPs were analysed by HPLC/APCI-MS, using a data-dependent scan mode (3 events) on an HPLC system equipped with an ion trap MS, as described in Talbot et al. (2007) and van Winden et al. (2012). Relative BHP concentrations were semi-quantitatively estimated based on the response factor of authentic standards (M. Rohmer; Strasbourg, France; Cooke et al., 2008), with a typical reproducibility of $\pm 20 \%$, according to Cooke et al. (2009).

\subsubsection{Bulk sedimentary organic matter and suspended particulate matter}

Freeze-dried core tops from 8 stations between 900 and $3000 \mathrm{~m}$ for sedimentary organic matter, and punches from $0.7 \mu \mathrm{m}$ GFF filters for suspended particulate organic matter, were decalcified with $2 \mathrm{~N} \mathrm{HCl}$, washed, freeze-dried, and subjected to analysis via a Flash EA 1112 Series (Thermo Scientific) analyser, coupled via a Conflo II interface to a Finnigan Delta ${ }^{\text {plus }}$ mass spectrometer as described by Lengger et al. (2014; sediment) and Pitcher et al. (2011; filters). Standards for $\delta^{13} \mathrm{C}$ analysis were acetanilide and benzoic acid and samples were analysed in duplicate. 
This is a non-peer reviewed preprint: version 2 of a manuscript submitted to Global Biogeochemical Cycles, which has been modified according to reviewers' comments and is currently in review again at Global Biogeochemical Cycles.

\section{Results}

To quantify the provenance of sedimentary organic matter and the contribution of anammox from the OMZ, we analysed the isotopic composition of sedimentary organic matter deposited in close spatial proximity over a large depth gradient in the Arabian Sea, as well as the isotopic composition of biomarker lipids derived from anammox bacteria, chemoautotrophic microbes living in the OMZ. In order to determine whether these were water-column derived or sedimentary, we used stable isotope probing experiments on sediments retrieved from within and below the OMZ.

\section{1. $\delta^{13} \mathrm{C}$ values of $\mathrm{C}_{\text {org }}$}

$\delta^{13} \mathrm{C}$ values of $\mathrm{C}_{\text {org }}$ in surface sediments were low (-21.5\%) at P900 and increased with water depth to $-20.2 \%$ at $\mathrm{P} 2500$ (Fig. $1 \mathrm{~d}$ ). $\delta^{13} \mathrm{C}_{\text {org }}$ values correlated positively and linearly (Slope $0.0057, \mathrm{R}^{2}=0.90$, Figure $1 \mathrm{e}$ ) with oxygen exposure times as calculated by Koho et al. (2013) and Lengger et al. (2014). Similarly, organic carbon content in the core tops was negatively correlated with oxygen exposure times $\left(R^{2}=0.93\right.$, from Lengger et al., 2014). The increase mirrors the decrease in \% TOC - and thus progressing degradation - with increasing oxygen exposure time (Fig. 1b,c, Lengger et al., 2014). At P900, where the whole depth of the core was analysed, values increased slightly with depth, from $-21.5 \%$ at the surface, to $-20.9 \%$ (Fig. 3). $\delta^{13} \mathrm{C}$ values of particulate organic carbon (suspended particulate organic matter) decreased throughout the water column from -19 to $-21.8 \%$, though with a substantially ${ }^{13} \mathrm{C}$ depleted, yet unexplained, value at the very surface (20 m depth) of $-22.9 \%$ (Fig. S1).

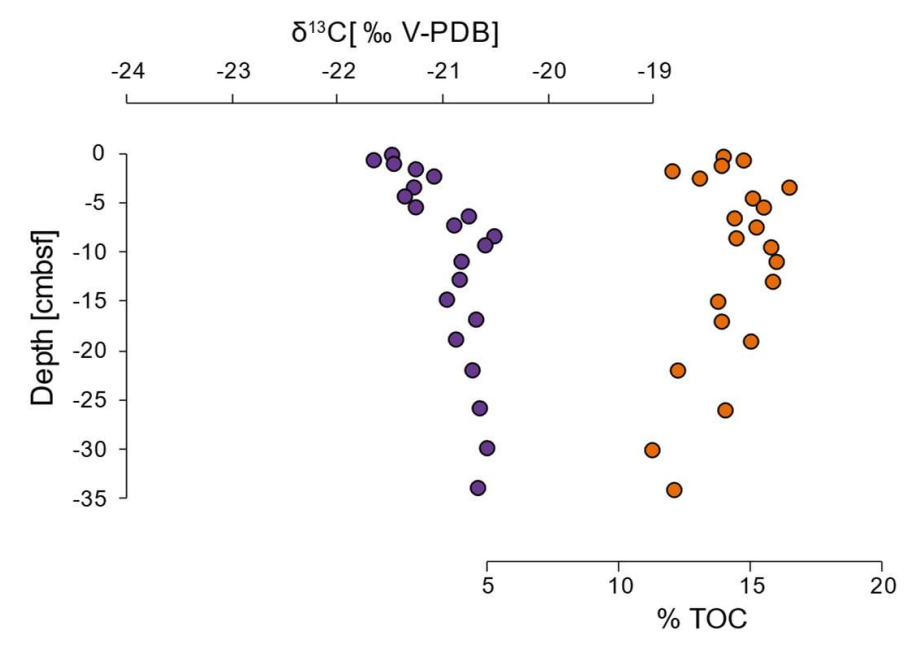

Figure 3. Depth profile of $\delta^{13} \mathrm{C}_{\text {org }}$ and \% TOC in an unamended core at P900.

\subsection{Biomarkers}

\subsubsection{Bacteriohopanepolyols (BHPs)}

Analysis of BHPs in the Arabian Sea cores using both HPLC-APCI-MS and HTGC-MS, all showed that BHT', specific for Scalindua, was abundant, and the fractional abundance of BHT's when compared to the sum of BHT and BHT' ranged from 0.4 to 0.6 . Other, relatively non-source-specific, BHPs were also present: BHT, 35-aminobacteriohopane-32,33,34-triol 
This is a non-peer reviewed preprint: version 2 of a manuscript submitted to Global Biogeochemical Cycles, which has been modified according to reviewers' comments and is currently in review again at Global Biogeochemical Cycles.

(aminotriol), bacteriohopane-31,32,33,34,35-pentol (BHpentol), bacteriohopanetetrol cyclitol ether (BHT-CE) and anhydro-BHT (Fig. S3). The relative concentrations of bacteriohopanetetrols were 75 to $96 \%$ of total bacteriohopanepolyols, an order of magnitude higher than other BHPs (Fig. S3). HTGC-MS was able to detect BHT, BHT' and BHpentol (Fig. S2), as well as small amounts of anhydroBHT, a BHT degradation product, and BHP-570, which has been tentatively identified by Sessions et al. (2013) as acetylated bacteriohopanediol, possibly also a degradation product of bacteriohopanetetrol. In the core from P900, the ratio of BHT’ over BHT increased with depth (Fig. S4).

We also analysed the BHP content of sediment cores incubated with ${ }^{13} \mathrm{C}$-labelled organic matter at both sites under the different conditions detailed by Pozzato et al. (2013 a, b), which was respired and generated ${ }^{13} \mathrm{C}$-labelled DIC, allowing to trace autotrophic processes such as anammox. No changes were noted, except for in P900; in those, BHT abundance increased (i.e. BHT'/BHT decreased), indicating that some of the sedimentary BHT could have been produced in situ (Fig. S4).

\subsubsection{BHT and BHT' $\delta^{13} \mathrm{C}$ values}

To establish the isotopic difference of BHT and BHT' derived from anammox we analysed biomass obtained from a batch reactor. BHT and BHT' were the main biohopanoids in the biomass from ' $\mathrm{Ca}$. S. profunda' detected by HTGC-MS (Fig. S2b). In addition to being present in ' $\mathrm{Ca}$ Scalindua sp.' anammox bacteria, BHT is a ubiquitous lipid common to many bacteria, BHT', however, is specific to $C a$ Scalindua sp.' in marine environments (Rush et al., 2014). The $\delta^{13} \mathrm{C}$ values of BHT and BHT' were identical within the error of analysis ( -49 and $48 \%$, respectively; Table 1), indicating identical fractionation and thus biosynthetic pathways for both lipids.

In the Arabian Sea sediments (all unamended cores), BHT was markedly enriched in ${ }^{13} \mathrm{C}$ relative to BHT', with values ranging from -24.7 to $-28.8 \%$ and -39.1 to $-48.1 \%$, respectively (Figs. 4b-c). At P1800 (below the OMZ), BHT and BHT' were slightly more depleted in ${ }^{13} \mathrm{C}$, with BHT at $-27 \pm 3 \%$ and BHT' at $-47 \pm 4 \%$, as compared to $-26 \pm 1 \%$ and $-43 \pm 5 \%$ for BHT and BHT' at P900 (in the OMZ). However, the difference between P900 and P1800 was not statistically significant for either BHT or BHT'. Moreover, even though the proportion of BHT' increased with depth in the anoxic core, the $\delta^{13} \mathrm{C}$ values did not change. We also analysed BHT and BHT' in the cores that had been incubated with ${ }^{13} \mathrm{C}$-labeled POM and DOM, and these showed no indication of ${ }^{13} \mathrm{C}$-enrichment in BHT'. Excluding outliers (defined by a Grubbs test at 99\% confidence level and indicated in Table 1), BHT' values were on average $-48 \pm 4 \%$ and $46 \pm 2 \%$ at P1800, and P900, respectively. BHT was slightly enriched compared to the unamended incubations at $3 \mathrm{~cm}$ depth $\left(\Delta \delta^{13} \mathrm{C}=4.6 \pm 0.7 \%\right)$, but not at $1 \mathrm{~cm}$ depth. BHpentol concentrations were too low to allow reliable isotopic determination, and anhydroBHT and BHP570 co-eluted with other compounds, also precluding their isotopic characterization.

\section{Discussion}

\subsection{Origins of BHT and BHT' - a biomarker for anammox}

BHT', a biomarker likely unique for annamox in marine environments (Rush et al., 2014,), is highly abundant in the sediment and occurred throughout both sediment cores (Fig. 4a), suggesting a significant contribution of anammox biomass to sedimentary organic matter. In 
This is a non-peer reviewed preprint: version 2 of a manuscript submitted to Global Biogeochemical Cycles, which has been modified according to reviewers' comments and is currently in review again at Global Biogeochemical Cycles.

the anoxic core (P900), BHT and BHT' were present in concentrations at least an order of magnitude higher than other BHPs (Fig. S2), and BHT' was the most abundant of the two stereoisomers (Fig. 4a). The high fractional abundance of BHT' over the sum of BHT and BHT' $(0.4-0.6)$ is contrary to our expectations, as BHT is a ubiquitous lipid and presumed to derive from both anammox and non-anammox sources such as cyano- and many other bacteria (Pearson and Rusch, 2009); it is, therefore, expected to be abundant in most depositional contexts. Lower proportions of BHT were reported previously in nearby core tops $(0.22-0.30)$ by Saenz et al. (2011); this could be caused by a difference in settings, or in BHP extraction protocol. However, the high proportions of BHT' observed in the Arabian Sea are not unprecedented: they are slightly lower than BHT' proportions in sediments underlying the Humboldt Current System OMZ offshore Peru (0.45 - 0.69 in surface sediments, Matys_et_al._.2017).

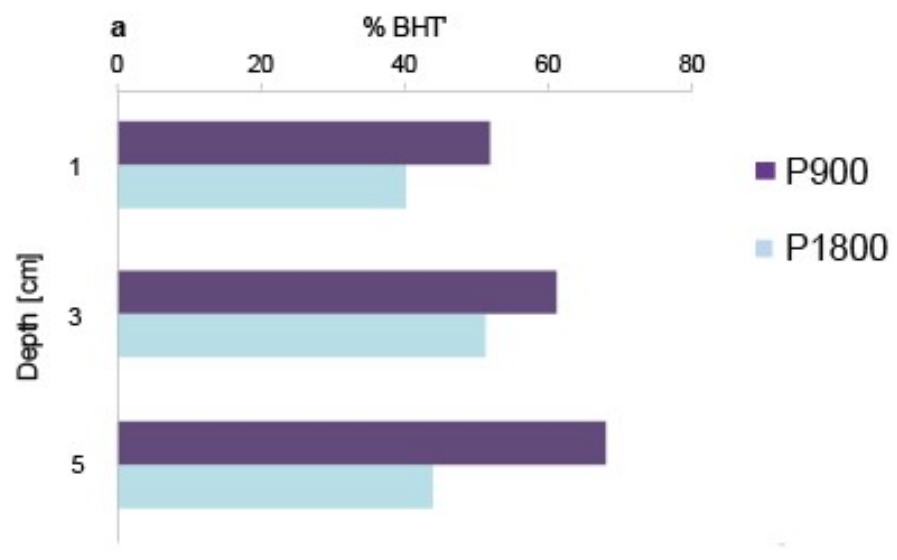

b $\mathbf{P} 1800$

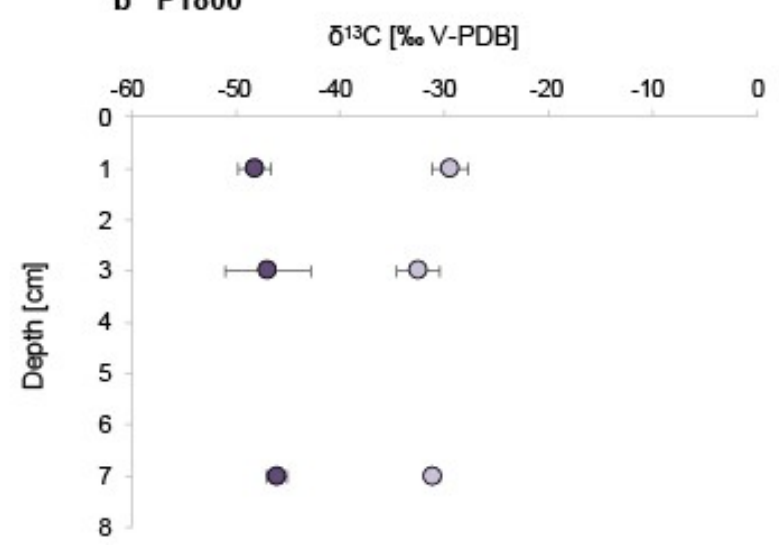

c P900

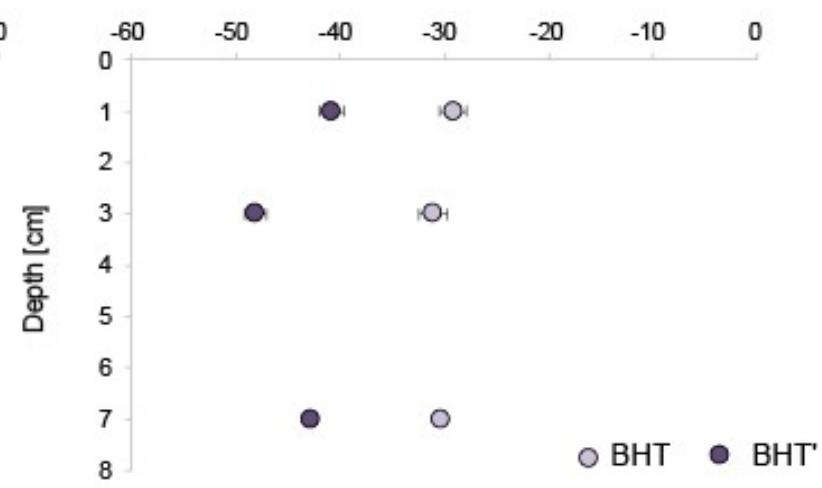

Figure 4. Anammox biomarkers in unamended Arabian Sea sediment. Panel (a) shows the proportion of BHT' relative to BHT+BHT', panels (b) and (c) show the $\delta^{13} \mathrm{C}$ values of BHT and $\mathrm{BHT}^{\prime}$ in the unamended oxic (P1800) and anoxic core (P900), respectively.

Supporting evidence for the unique source of BHT' comes from its ${ }^{13} \mathrm{C}$ values of -40 to $50 \%$. Anammox bacteria are known to fractionate strongly against $\delta^{13} \mathrm{C}$, with up to $26 \%$ o fractionation observed for biomass in cultures and sediment, with even more strongly depleted BHT and BHT' (Brocadia sp. by 47 \%o and Scalindua sp. by 49 \% against DIC; Schouten et al., 2004). Anammox bacteria within the oxygen minimum zone and using dissolved inorganic 
This is a non-peer reviewed preprint: version 2 of a manuscript submitted to Global Biogeochemical Cycles, which has been modified according to reviewers' comments and is currently in review again at Global Biogeochemical Cycles.

carbon, which is up to $2 \%$ lighter within the OMZ than at the surface (Kroopnick, 1984), are likely to produce such ${ }^{13} \mathrm{C}$-depleted lipids. In line with an anammox origin, BHT' here is decidedly more depleted than other biomarkers in the Arabian Sea (cf. Wakeham and McNichol, 2014), though distinctly depleted highly branched isoprenoids (HBIs, $-37 \%$ ) have been found in Arabian Sea cores from the Holocene (Schouten et al., 2000).

BHT, however, is much more enriched in ${ }^{13} \mathrm{C}$ in the Arabian Sea sediments, with values of -29 to $-30 \%$ (Fig. $4 \mathrm{~b}, \mathrm{c}$ ). This is in contrast to anammox cultures, where BHT and BHT' are produced with identical isotope values (Fig. S4, Table 1). This strongly supports the idea that BHT has a mixed origin. The sources for BHT could be varied: cyanobacteria or heterotrophic bacteria thriving in the OMZ or the sediment (Pearson and Rusch, 2009), and possibly including nitrite-oxidising bacteria (Kharbush et al., 2018). The $\delta^{13} \mathrm{C}$ values of BHT derived from these alternative sources are poorly constrained (Hayes, 2001; Kharbush et al., 2018; Pearson, 2010; Sakata et al., 1997; Schouten et al., 1998). However, for heterotrophic bacteria, values similar to the consumed OM minus the depletion associated with polyisoprenoids of 6-8\% are expected (Pancost and Sinninghe Damsté, 2003). Similar values would be expected for cyanobacterial lipids, too, as those are depleted by $22-30 \%$ compared to dissolved $\mathrm{CO}_{2}$, which varies from 0 to $2 \%$ in the photic zone. Methane cycling could also lead to ${ }^{13} \mathrm{C}$ depleted $\mathrm{OM}$, but is not important in the Arabian Sea (Lüke et al., 2016), and there is no biomarker evidence for it, such as ${ }^{13} \mathrm{C}$ depleted archaeal lipids, or methylated BHPs. Thus, a BHT $\delta^{13} \mathrm{C}$ value of $-30 \%$ suggests heterotrophic and other bacterial sources, possibly mixed with an anammox source.

Anammox activity has been shown to occur both within the OMZ water column (Jensen et al., 2011; Lüke et al., 2016; Pitcher et al., 2011; Villanueva et al., 2014) as well as in sediments (Sokoll et al., 2012; Devol, 2015). To test whether the anammox-derived biomarkers are formed in the sediment, the labelled cores were incubated for 7 days with particulate and dissolved organic matter (Table 1), which resulted in the substantial incorporation of ${ }^{13} \mathrm{C}$ into bacterial fatty acids, as well as generating ${ }^{13} \mathrm{C}$-enriched $\mathrm{CO}_{2}$ due to heterotrophic respiration (up to $14 \%$ of the added $\mathrm{C}$ was respired, Pozzato et al., 2013a,b). Anammox bacteria are autotrophic, and it is therefore likely that an active sedimentary community would result in some uptake of this ${ }^{13} \mathrm{C}$ labelled $\mathrm{CO}_{2}$ formed by respiration. However, no significant labelling was observed in BHT' or BHT (Table 1, Table S1), suggesting that most of this pool is water-column derived. Further, BHT and BHT' are also present in the surface of the oxic sediments (P1800), in proportions similar to the anoxic sediments at P900. Even if anammox growth was too slow for labelling to take effect, substantial sedimentary production would have resulted in a decreasing $\delta^{13} \mathrm{C}$ value of BHT' in the unamended cores, as DIC gradually becomes more ${ }^{13} \mathrm{C}$ depleted with sediment depth (Fernandes et al., 2018), but this is not observed (Fig. 4bc). Collectively, these data support the idea that the vast majority of BHT' is derived from anammox bacteria living in the OMZ of the water column, and that BHT also has a predominant pelagic origin with limited sedimentary production.

The $\delta^{13} \mathrm{C}$ values of geohopanoids (i.e. the geological degradation product of biohopanoids such as BHT and BHT') can exhibit dramatic variability, and often pronounced depletion in terrestrial (Pancost et al., 2007) and marine settings (Köster et al., 1998). These are commonly attributed to aerobic methane oxidising bacteria, and thus regarded as evidence for a significant contribution of methane oxidisers to sedimentary organic matter. However, our data show that hopanes of -35 to $-50 \%$ could also indicate the presence of a significant amount of anammox bacteria in an anoxic water column. Several factors could attenuate the anammox signal. The decrease of 
This is a non-peer reviewed preprint: version 2 of a manuscript submitted to Global Biogeochemical Cycles, which has been modified according to reviewers' comments and is currently in review again at Global Biogeochemical Cycles.

biohopanoids in structural complexity upon degradation means that the anammox signal would be diluted by mixing with aerobically and anaerobically produced hopanoids such as those of Geobacter (Fischer et al..2 2005; Härtner et al..2 2005). Chemoautotrophs operating in euxinic settings employ biochemical pathways resulting in ${ }^{13} \mathrm{C}$-enriched biomass and lipids compared to DIC (van Breugel et al., 2005b). However, in anoxic basins such as the Black Sea or anoxic fjords, remineralization of organic matter also results in distinctly depleted $\delta^{13} \mathrm{C}_{\mathrm{DIC}}$ below the chemocline (-12\%o; Fry et al., 1991; Volkov, 2000). This may explain why, in some marine anoxic settings where we might expect to see an anammox signature, the ${ }^{13} \mathrm{C}$ depletion of hopanes parallels that of algal biomarkers (Sinninghe Damsté et al., 2008; van Breugel et al., 2005a). Nonetheless, we suggest that potential anammox contributions to the sedimentary hopanoid pool should be considered when interpreting their abundances, distributions and isotopic compositions.

\subsection{Origin of sedimentary organic matter}

The Murray Ridge represents an open ocean setting, and the selected coring sites were in close proximity to each other, with no substantial terrigenous contribution (Koho et al., 2013; Lengger et al., 2014, 2012b; Nierop et al., 2017; Fig. 1d). Despite this, $\delta^{13} \mathrm{C}$ values of sedimentary organic matter of a purely marine origin varied: The value at the shallowest location (-21.5\%; P900), within the OMZ, was $2.5 \%$ more depleted than the estimated value for surface water-derived OM -19.8\% (Fontugne and Duplessy, 1986), and the $\delta^{13} \mathrm{C}$ values of sedimentary $\mathrm{C}_{\text {org }}$ increased with increasing oxygen bottom water concentrations / oxygen exposure time (Fig. 1e). These observations agree with earlier studies from this setting. Cowie et al. $(2009,1999)$ detected similar trends in surficial sediments across different settings in the Arabian Sea, with values of $-21 \%$ within and $-19 \%$ above and below the OMZ. Organic matter in sediment traps collected in the north western Arabian Sea (i.e. sinking POC) had a $\delta^{13} \mathrm{C}$ value of $-22.4 \%$ (composite of the OMZ between 500 and $900 \mathrm{~m}$ depth). The corresponding sedimentary $\delta^{13} \mathrm{C}_{\text {org }}$ value, from oxygenated bottom waters at $1445 \mathrm{~m}$ depth, was, however, more enriched $(-20.8 \%$; Wakeham and McNichol, 2014). Fernandes et al. (2018) detected similar, though less pronounced, trends in sediments collected from the Pakistan margin. An increase in $\delta^{13} \mathrm{C}$ with enhanced degradation, i.e. ${ }^{13} \mathrm{C}$-enriched sediments vs. depleted POM, was also observed in the South China Sea (Liu et al., 2007), and in the Eastern Tropical North Pacific (Jeffrey et al., 1983).

Despite its common occurrence in OMZ settings, this trend is unusual and, at present, not explained: degradation of organic carbon in marine environments usually preferentially removes isotopically heavy carbon (Hatch and Leventhal, 1997), causing a depletion in $\delta^{13} \mathrm{C}$ with increased degradation of the sediment. This can be due to the removal of the more labile marine carbon, and subsequent relative enrichment of terrigenous organic material of a lower initial reactivity and lower $\delta^{13} \mathrm{C}$ values (Huguet et al., 2008; Middelburg et al., 1993). However, progressive depletion also occurs in areas with purely marine input; this is due to preferential loss of ${ }^{13} \mathrm{C}$-enriched carbohydrates over the more ${ }^{13} \mathrm{C}$-depleted lipids, and preferential degradation of easily accessible material over biopolymers (Spiker and Hatcher, 1987), and polymerization and elimination of functional groups (Galimov, 1988; Balabane et al., 1987). Conversely, sulfurization, a process observed in euxinic settings appears to preferentially preserve ${ }^{13} \mathrm{C}$-enriched material such as carbohydrates (Van Kaam-Peters et al., 1998); however, this process is not expected to occur here - the Arabian Sea is anoxic but not sulfidic (Ulloa et al., 2012) and has not experienced euxinia for the past $120 \mathrm{ka}$ (Schenau et al., 2002). 
This is a non-peer reviewed preprint: version 2 of a manuscript submitted to Global Biogeochemical Cycles, which has been modified according to reviewers' comments and is currently in review again at Global Biogeochemical Cycles.

Nonetheless, in Arabian Sea sediment, $\delta^{13} \mathrm{C}_{\text {org }}$ values increased by $1.8 \%$ with increasing oxygen exposure time and thus increasing degradation; at the same time, organic carbon contents decreased from 60 to $10 \mathrm{mg} \mathrm{g} \mathrm{dw}^{-1}$, indicating progressing remineralization (Fig. 1c, Lengger et al., 2014). Cowie (2005) attributed this to the contribution of - potentially - organic matter from the facultatively autotrophic, chemosynthetic sulfur-bacterium Thioploca sp., which has been observed in the Arabian Sea (Schmaljohann et al., 2001). However, Thioploca sp. has only been reported for shelf and upper slope sediments in the Arabian Sea (above and upper part of OMZ), and it is unlikely that the sulfur-dependent Thioploca sp. could have caused this significant depletion by chemoautotrophy, as sulfide concentrations are negligible within the OMZ (Kraal et al., 2012), and there is no evidence for the production of severely ${ }^{13} \mathrm{C}$-depleted biomass by filamentous sulfur bacteria (Zhang et al., 2005). Further, the depletion is not only observed in sediments, but also in particle fluxes (Wakeham and McNichol, 2014), which strongly suggests the exclusion of sedimentary sources for ${ }^{13} \mathrm{C}$-depleted organic matter. This is also supported by

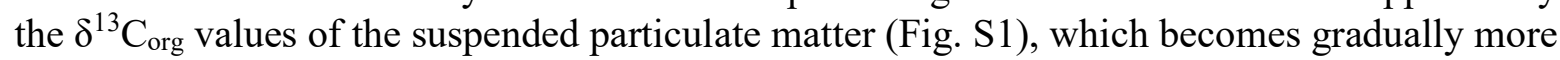
depleted with depth.

An active nitrogen-cycle in the water column within the Arabian Sea OMZ is undisputedly present, with heterotrophic denitrifying bacteria, nitrifying archaea, nitriteoxidising and anammox bacteria present in high abundances (Lüke et al., 2016; Villanueva et al., 2014). The ${ }^{13} \mathrm{C}$ fractionation for the carbon fixation pathways employed by nitrifying archaea (3Hydroxypropionate/4-Hydroxybutyrate, 3-HP/4-HB) is similar to that of phytoplankton using Rubisco (Könneke et al., 2012). The biomass of heterotrophic denitrifiers is close to the value of the source organic matter (1\%o more enriched; Hayes, 2001), and the biochemical pathway employed by nitrite oxidisers (reverse TCA cycle) produces ${ }^{13} \mathrm{C}$-enriched biomass (Pearson, 2010). Anammox bacteria, however, are abundant and active in the Arabian Sea (Jensen et al., 2011) and known to produce highly ${ }^{13} \mathrm{C}$-depleted biomass by inorganic carbon fixation (Schouten et al., 2004). Anammox bacteria, and other, yet undescribed chemoautotrophs, could thus present a potential pathway for addition of ${ }^{13} \mathrm{C}$-depleted organic matter to sinking organic matter, a hypothesis we explore further below.

The water-column derived ${ }^{13} \mathrm{C}$-depleted BHT', in combination with the unusual $\delta^{13} \mathrm{C}_{\text {org }}$ trends, suggests that there may be a substantial contribution of ${ }^{13} \mathrm{C}$ depleted organic carbon, produced by anammox bacteria, to the sedimentary organic matter. Based on BHT' $\delta^{13} \mathrm{C}$ values determined in this study, and the fractionation factor associated with anammox lipid biosynthesis of $16 \%$ (lipid versus total biomass; Schouten et al., 2004), we can estimate a $\delta^{13} \mathrm{C}$ value for anammox biomass: of ca.-28.6 $\pm 6 \%$, which is similar to the expected value calculated from Ebiomass-DIC (22-26 \%; Schouten et al., 2004) and the generally observed DIC value in the Arabian Sea OMZ at depth, $0 \%$ (Moos, 2000). This is significantly depleted compared to phytoplankton biomass in the Arabian Sea (-19.8 \%o, Fontugne and Duplessly, 1978), and would add depleted organic carbon to the sinking POM.

We modelled the contribution of annamox biomass $\left(\chi_{\text {anammox }}\right)$ to SOM using an

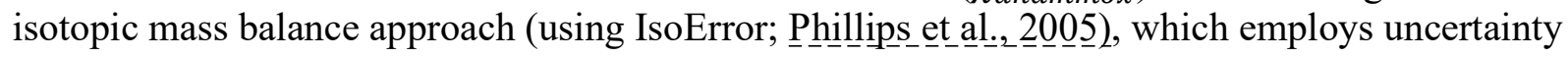
propagation and error estimates and allows the determination of contributions of likely sources of organic matter to the sediment. The end member value of $-19.8 \pm 0.5 \%$ was used for phytoplankton-derived SOM (Fontugne and Duplessy, 1986; Ziegler et al., 2008). This value is slightly lower than the $-19 \%$ observed from the surface particulate carbon, but is representative of sedimentary organic matter, as it accounts for the decreased $\delta^{13} \mathrm{C}$ values of POM caused by 
This is a non-peer reviewed preprint: version 2 of a manuscript submitted to Global Biogeochemical Cycles, which has been modified according to reviewers' comments and is currently in review again at Global Biogeochemical Cycles.

degradation of ${ }^{13} \mathrm{C}$ enriched compounds such as carbohydrates (Close, 2019; Ziegler et al., 2008). More recent values for phytoplankton $\delta^{13} \mathrm{C}$ are, to the best of our knowledge, not available. Planktonic, sinking organic matter, and organic material produced by heterotrophs also contribute to sedimentary OM. However, this OM value would likely be similar to the organic matter assimilated (Blair et al., 1985; 2001). $-28.6 \pm 6 \%$ was used for anammox-derived organic carbon, as derived from the $\delta^{13} \mathrm{C}$ value of BHT' and $\varepsilon_{\mathrm{bm} / \mathrm{ipid}}$ of $16 \pm 4 \%$ (Schouten et al., 2004; Table 1; uncertainty represents combined standard deviations of $\delta^{13} \mathrm{C}_{\mathrm{BHT}}$, and $\left.\varepsilon_{\text {lipid/bm }}\right)$. The $\delta^{13} \mathrm{C}$ value $-21.5 \%$ of surface sediment $\mathrm{C}_{\text {org }}$ in the $\mathrm{OMZ}$ was used as the value of the mixture (Table 1):

$$
\chi_{\text {anammox }} \cdot \delta^{13} C_{\text {anammox }}+\chi_{P P} \cdot \delta^{13} C_{P P}=-21.5 \%
$$

The modelling, assuming the above end member contributions and their statistical uncertainties, yields a proportion of anammox with a mean of approximately $17 \%$ (Fig. 5), and confirms that, with $95 \%$ confidence, anammox contribution to the sedimentary organic matter is between 3 and $30 \%$ among the different cores. This suggests that some of the sedimentary organic matter (SOM) present at P900 is anammox-derived. However, other chemoautotrophic bacteria also present, or suspected to be present, in the Arabian Sea OMZ (e.g. ammonia-oxidizing archaea, Pitcher et al., 2011) possess metabolisms which would lead to different $\delta^{13} \mathrm{C}$ values, and could therefore be diluting this signal (Hayes, 2001; Pearson, 2010). These results suggest that the contribution of prokaryotic organic material produced in the OMZ to SOM is larger than estimated in this simple, two-component mass balance. A three-source model resolving heterotrophic bacteria or degraded OM, anammox bacteria and phytoplankton was solved with SIAR (Parnell et al., 2010) and yielded similar results (not shown).

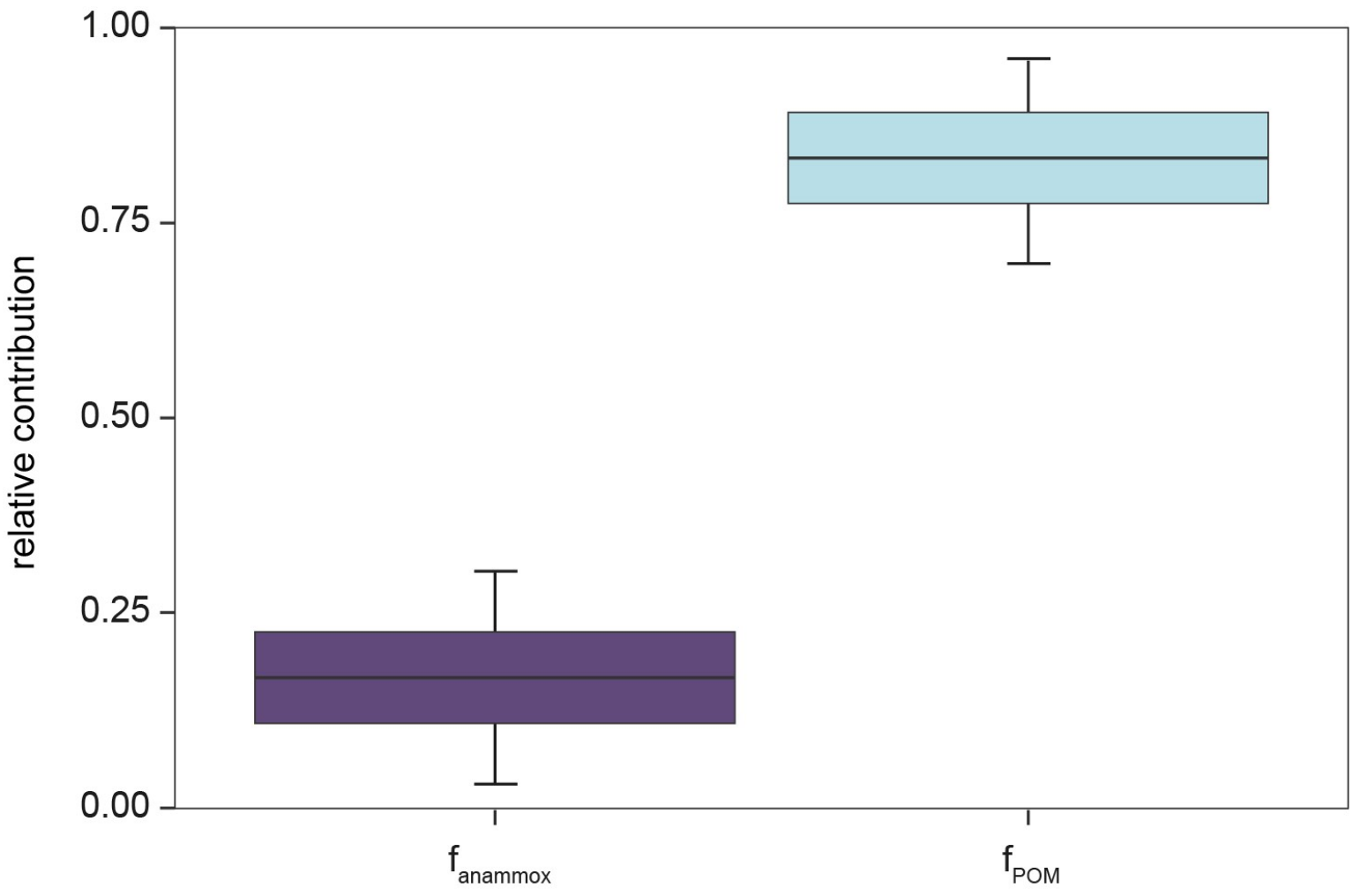


This is a non-peer reviewed preprint: version 2 of a manuscript submitted to Global Biogeochemical Cycles, which has been modified according to reviewers' comments and is currently in review again at Global Biogeochemical Cycles.

Figure 5. Results from the isotope mass balance model, showing the calculated means, standard error, and confidence intervals for contribution from anammox, and planktonic-derived OM (POM) to the surface sediment at P900.

This estimate, at a first glance, appears large. However, we can convert experimental rates of anammox-mediated ammonia oxidation of $27-38 \mathrm{nmol} \mathrm{L}^{-1} \mathrm{~d}^{-1}$ as determined in the Arabian Sea (Jensen et al., 2011) and alternative rates of $0.24-4.32 \mathrm{nmol} \mathrm{L}^{-1} \mathrm{~d}^{-1}$ estimated by Ward et al. (2009), to carbon fixed using stoichiometric rates determined for anammox bacteria of $0.07 \mathrm{~mol} \mathrm{C} \mathrm{mol} \mathrm{N} 2^{-1}$ (Jetten et al., 2001; Strous et al., 1999; van de Vossenberg et al., 2008). Assuming a production depth of 300 to $900 \mathrm{~m}$ water depth, with a maximum at $600 \mathrm{~m}$ (Pitcher et al., 2011), anammox production over the whole depth could be estimated using Equation 2 (see Fig. S5),

$$
P=\frac{(k \cdot 600)}{2}
$$

in which $k$ corresponds to maximum rate at maximum production depth calculated from aforementioned published anammox rates ( $k$ equals $138.7-9855 \mu \mathrm{mol} \mathrm{m}^{-3} \mathrm{yr}^{-1}$, Jensen et al. $2011 ; 87.6-1576.8 \mu \mathrm{mol} \mathrm{m}^{-3} \mathrm{yr}^{-1}$, Ward et al. 2009; Fig. S5).

Using this equation, we calculated that water-column anammox bacteria produce up to $3.5 \mathrm{~g}$ organic $\mathrm{C} \mathrm{m}^{-2} \mathrm{yr}^{-1}$. These estimates dwarf sedimentary anammox rates, with C-fixation determined to be at $64 \mathrm{pg}$ organic $\mathrm{C} \mathrm{m}^{-2} \mathrm{yr}^{-1}$ in the Arabian Sea (Sokoll et al., 2012), indicating that most of the anammox carbon in the sediment is water-column derived. Given organic carbon accumulation rates (Lengger et al., 2012b) of 3 to $5 \mathrm{~g} \mathrm{C} \mathrm{m}^{-2} \mathrm{yr}^{-1}$ at P900 and assuming a $17 \%$ anammox contribution to sedimentary organic matter, a maximum of $24 \%$ of annually produced, water-column anammox biomass is preserved in this anoxic setting. Within the sediment from the OMZ, as seen from a sedimentary depth profile at P900 in the OMZ (Fig. 3), $\delta^{13} \mathrm{C}_{\text {org }}$ also shifts to higher values with depth, to a maximum of $-20.8 \%$ at $8 \mathrm{cmbsf}$. However, contrary to oxic degradation, no decrease in SOM contents occurs over the first $14 \mathrm{~cm}$ (Fig. 3). In this case, the increase in $\delta^{13} \mathrm{C}_{\text {org }}$ likely reflects input by other sedimentary autotrophs, producing enriched organic carbon. This suggests that the ${ }^{13} \mathrm{C}$-depleted SOM signal from the $\mathrm{OMZ}$ is not completely preserved.

Other chemoautotrophs, where specific biomarkers are not available, could also contribute to the SOM: at depth, the increased availability of $\mathrm{CO}_{2}$ derived from heterotrophic respiration of the POM pool would result in greater discrimination against ${ }^{13} \mathrm{C}$ (Freeman et al., 1994; Freeman, 2001). An example are lipids of ammonia-oxidising archaea, which were more depleted when deposited in the OMZ than below the OMZ (Table S2), suggesting that some of those were produced in the produced in the OMZ and transported to the sediment (Lengger et $\underline{a l}_{-2}$ 2014, 2012b; Schouten et al., 2012).. However, as these archaeal lipids present a mixed pelagic and sedimentary signal, quantitative estimates are not possible.

Hence, chemoautotrophic carbon fixation could explain the low $\delta^{13} \mathrm{C}$ values of sedimentary OM observed within the OMZ. As the newly produced organic carbon is more labile than surface-produced organic matter, it would degrade more quickly upon exposure to 
This is a non-peer reviewed preprint: version 2 of a manuscript submitted to Global Biogeochemical Cycles, which has been modified according to reviewers' comments and is currently in review again at Global Biogeochemical Cycles.

oxic bottom waters. This poorer preservation of anammox biomass results in a shift back towards the ${ }^{13} \mathrm{C}$ signature of the primary photosynthetic production, which is observed as the enrichment in sedimentary $\delta^{13} \mathrm{C}_{\text {org }}$ with increasing oxygen exposure times (Fig. 1e). A likely explanation for this lability of anammox biomass is that, due to the lack of zooplankton in the OMZ, this organic matter is not fecal-pellet packaged or adsorbed to inorganic particles and thus not matrix protected (cf. Burdige, 2007). Wakeham et al. (2002) analysed the biomarker fluxes in sinking particles in the Arabian Sea, and they also found that surface-produced lipids such as alkenones (which would be fecal pellet packaged) were exceptionally well-preserved compared to the total organic carbon of the SPM. Gong and Hollander (1997) also noted an enhanced contribution of bacterial biomass to sediment deposited under anoxic conditions in the Santa Monica Basin, when compared to sediment located in nearby oxygenated bottom waters. Studies examining carbon fluxes in the Arabian Sea (Keil et al., 2016) and the Cariaco basin (Taylor et al., 2001) invoked the addition of chemoautotrophically derived carbon from a midwater source in order to explain the enhanced carbon fluxes observed, even if oxygen depletion and other factors such as the lack of zooplankton were taken into account.

\subsection{Quantifying the biological pump and remineralization rates}

Models of the biological pump consider primary production, particle fluxes, oxygen concentrations, and respiratory rates. Sinking organic matter is traditionally regarded as a reflection of exported organic material from the photic zone, and export models consider remineralization and C-loss (Cabré et al., 2015; Schlitzer, 2002), based on claims that bacterial contributions do not sink (Buesseler et al., 2007). However, relying on these parameters, estimates of particulate organic carbon flux in the Arabian Sea are generally too low to sustain experimentally observed denitrification, bacterial production, and oxygen deficiency in the

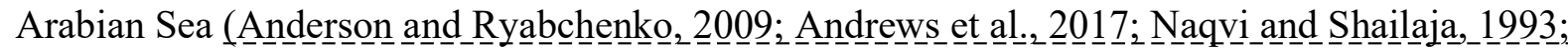
Rixen and Ittekk ${ }_{1}$ ot, 2005). New mechanisms have been discovered that can explain downward transport of smaller particles and bacteria, such as particle aggregation (Burd and Jackson, 2009), and mixed layer transport mechanisms (Bol et al., 2018), which enable the consideration of the contribution of anammox biomass to sinking OM.

In previous work, the deficit in modelled and observed C-utilization estimated from denitrification was as high as $70 \mathrm{~g} \mathrm{C} \mathrm{m}^{-2} \mathrm{y}^{-1}$ (Naqvi and Shailaja, 1993). Including anammox in models of the nitrogen cycle can account for at least $30 \%$ or more of the nitrogen losses, as well as accounting for organic carbon production, thereby reconciling some of this budget discrepancy. More recently, the combined inclusion of mesopelagic zooplankton and heterotrophic bacteria into 3D models resulted in much lower bacterial productivity $\left(4.7 \mathrm{~g} \mathrm{C} \mathrm{m}^{-2}\right.$ $\mathrm{y}^{-1}$ ) than observational estimates of $10.4 \mathrm{~g} \mathrm{C} \mathrm{m}^{-2} \mathrm{y}^{-1}$ (Anderson and Ryabchenko, 2009). Other recent models, combined with experimental observations of particle fluxes, suggest that at some stations, the lower oxycline is associated with 0.4 to $1.8 \mathrm{~g} \mathrm{C} \mathrm{m}^{-2} \mathrm{y}^{-1}$ increases in net carbon fluxes (Roullier et al., 2014). Horizontal transport, also from nepheloid layers, novel transport mechanisms from the mixed layer, and DOM, have previously been invoked as the missing carbon supply. Here, we estimate that an additional $3.5 \mathrm{~g} \mathrm{~m}^{-2} \mathrm{y}^{-1}$ of organic carbon are produced by anammox from DIC, with other chemoautotrophic processes possibly adding to this estimate. This also affects estimates of nitrogen losses and has direct implications for the forecasting of OMZs in a warming world. 
This is a non-peer reviewed preprint: version 2 of a manuscript submitted to Global Biogeochemical Cycles, which has been modified according to reviewers' comments and is currently in review again at Global Biogeochemical Cycles.

In paleoceanography, the $\delta^{13} \mathrm{C}$ values of total organic carbon are commonly used in combination with organic carbon contents in sediment cores to interpret changes in sea surface biogeochemistry and to discern the causes for ocean deoxygenation (Jenkyns, 2010; Meyers, 2014). Negative $\delta^{13} \mathrm{C}$ excursions are associated with either atmospheric injection of depleted $\mathrm{CO}_{2}$ and/or increased $\mathrm{CO}_{2}$ availability (Pagani, 2005; Pancost and Pagani, 2005), or a higher input of terrigenous organic matter. Positive excursions are inferred to reflect increased burial rates of organic carbon, i.e. the removal of 'light' carbon from the ocean-atmosphere reservoir (e.g. Kuyppers et_al.._2002;__enkyns _ 1985). An increase in TOC coinciding with a negative carbon isotope excursion has been observed in the sedimentary record numerous times. They are a prominent feature in OAE 1a (Leckie et al., 2002), during the PETM (Zachos et al., 2005), and in the Eastern Mediterranean during Sapropel deposition (Meyers and Arnaboldi, 2008). Our results show that if non-sulfidic OMZs expand to impinge on the sediment, a significant amount of ${ }^{13} \mathrm{C}$ depleted organic carbon can be preserved, changing the carbon isotope composition of organic matter by up to $-1.6 \%$ in the case of Arabian Sea surface sediments, and by -0.5 to $-1 \%$ in deeper sediments. When evaluating past events based on bulk $\delta^{13} \mathrm{C}$ values, the incorporation of chemoautotrophically produced carbon must thus be considered. This also further supports claims that calculations of $\mathrm{pCO}_{2}$ based on differences between $\delta^{13} \mathrm{C}$ of organic and inorganic carbon should not rely on bulk organic carbon that includes bacterial contributions, but instead use compound specific $\delta^{13} \mathrm{C}$ values derived from algae, consistent with previous investigations (Pancost et al., 1999; Pancost et al., 2013; reviewed by Witkowski et al., 2018). By extension, a deviation from the relationship between $\delta^{13} \mathrm{C}$ bulk OM and $\delta^{13} \mathrm{C}$ phytane could be an indicator for the chemoautotrophic contribution to sedimentary OM.

Chemoautotrophic metabolism in euxinic water columns, where often very low $\delta^{13} \mathrm{C}_{\mathrm{DIC}}$ values are observed (van Breugel et al., 2005a,b; Fry et al., 1991; Volkov, 2000), has previously been invoked as contributing to organic matter in these setting. Anammox, which has been shown to be an important process in the anoxic water column overlying euxinia (Kuypers et al., 2003), also needs to be considered. Anammox also plays an important role in the nitrogen cycle of Mediterranean sapropel events, even in sapropels where euxinia appears to have occurred (Rush et al., 2019), potentially causing a significant contribution of anammox to the depleted $\delta^{13} \mathrm{C}_{\text {org }}$ values of these sapropels. Previously, a conceptual model invoking chemoautotrophy has been invoked to explain e.g. the End-Permian (Luo et al., 2014) and the Lomagundi isotope excursion (Bekker et al., 2008).

Settings similar to the Arabian Sea, with $\leq 4.5 \mu \mathrm{mol} \mathrm{kg}^{-1} \mathrm{O}_{2}$, occur in the East Pacific and those settings in total occupy an area of 8.45 to $15 \times 10^{12} \mathrm{~m}^{2}$ (Karstensen et al., 2008; Hattori, 1983; Paulmier and Ruiz-Pino, 2009), or a volume of $0.46 \times 10^{15} \mathrm{~m}^{3}$ with $1.148 \times 10^{12} \mathrm{~m}^{2}$ in contact with the sediment (Helly and Levin, 2004). OMZs are expanding in size and in volume (Stramma et al., 2010; Queste et al., 2018), and anammox bacteria play a key role in these settings, particularly because they tolerate higher oxygen concentrations than denitrifiers (Dalsgaard et al., 2014). The labile organic matter added to the sinking carbon can fuel heterotrophic processes, further exacerbating oxygen depletion, and nitrogen loss by denitrification. For accurate future forecasting, it is imperative to reconcile experimental and model-based estimates. Novel, detailed observations explaining the vertical transport of bacterial biomass, and evidence from the isotopic composition of TOC and biomarkers for chemoautotrophic processes, such as shown here for anammox, will enable the further unravelling of the biogeochemical mechanisms underpinning present, past, and future OMZs. 
This is a non-peer reviewed preprint: version 2 of a manuscript submitted to Global Biogeochemical Cycles, which has been modified according to reviewers' comments and is currently in review again at Global Biogeochemical Cycles.

\section{Conclusions}

Combining the $\delta^{13} \mathrm{C}$ values of BHT', a biomarker from anammox bacteria, and the $\delta^{13} \mathrm{C}$ values of sedimentary organic matter allowed us to estimate the contribution of anammox to SOM in the Arabian Sea. This can be as much as $30 \%$ of organic matter deposited within the OMZ. In the sediments underlying the Arabian Sea, $\delta^{13} \mathrm{C}$ values of total organic matter can shift by 1 to $2 \%$ due to these bacterial contributions, but it remains unclear how well and under what conditions this signature is preserved. Our results suggest that chemoautotrophs (e.g. anammox bacteria) contribute more than previously believed to the burial of carbon in oxygen deficient zones, and remineralization rates are potentially higher than inferred from organic matter decreases. This implies that, when past occurrences of OMZs are evaluated based on $\delta^{13} \mathrm{C}$ values of SOM, a ${ }^{13} \mathrm{C}$-depleted contribution of bacteria needs to be considered. Chemoautotrophic carbon fixation thus represents a mechanism of $\mathrm{CO}_{2}$ removal from the pelagic water column, and contributes to fluxes of sinking organic carbon. It explains some of the mismatches in carbon budgets when experimental and modelling estimates are compared - and it should therefore be included in biogeochemical models predicting feedbacks to a warming world.

Acknowledgements: SKL was supported by Rubicon fellowship nr. 825.14.014 from the Netherlands Organization for Scientific Research (NWO). MJ, JJM, JSSD, and SS were supported by NESSC OCW/NWO 024002.001 and MJ, JSSD and DR by SIAM OCW/NWO 024002.002 grants. RSN and DR were supported by NERC grant ANAMMARKS NE/N011112/1 awarded to DR. JB is supported by a NERC GW4+ Doctoral Training Partnership studentship from the Natural Environment Research Council (NE/ L002434/1) and is thankful for the support and additional funding from CASE partner, Elementar UK Ltd. We thank Guylaine Nuijten (Radboud University) for maintaining the Scalindua biomass over the years. We thank Ian Bull and Alison Kuhl for support with instrumentation, and Jort Ossebaar and Kevin Donkers for support with TOC and bulk isotope analysis. We would also like to acknowledge the shipboard party of 64PE306, in particular chief scientist Gert-Jan Reichart, and Leon Moodley and Lara Pozzato, who provided us with samples from their incubation experiments. The associate editor S. Mikaloff-Fletcher and the referees, K. Freeman and A. Singh are thanked for their highly valued contributions to improving this manuscript.

Data statement: Data statement: All supporting data is included, and will be deposited on Pangaea as appropriate. 
This is a non-peer reviewed preprint: version 2 of a manuscript submitted to Global Biogeochemical Cycles, which has been modified according to reviewers' comments and is currently in review again at Global Biogeochemical Cycles.

\section{References}

Anderson, T. R., \& Ryabchenko, V. A. (2009). Carbon cycling in the Mesopelagic Zone of the central Arabian Sea: Results from a simple model. Washington DC American Geophysical Union Geophysical Monograph Series, 185, 281-297. https://doi.org/10.1029/2007GM000686

Andrews, O., Buitenhuis, E., Le Quéré, C., \& Suntharalingam, P. (2017). Biogeochemical modelling of dissolved oxygen in a changing ocean. Philosophical Transactions of the Royal Society A: Mathematical, Physical and Engineering Sciences, 375(2102), 20160328. https://doi.org/10.1098/rsta.2016.0328

Angelis, Y. S., Kioussi, M. K., Kiousi, P., Brenna, J. T., \& Georgakopoulos, C. G. (2012). Examination of the kinetic isotopic effect to the acetylation derivatization for the gas chromatographic-combustion-isotope ratio mass spectrometric doping control analysis of endogenous steroids: Kinetic isotopic effect to the acetylation derivatization of endogenous steroids. Drug Testing and Analysis, 4(12), 923-927. https://doi.org/10.1002/dta.408

Balabane, M., Galimov, E., Hermann, M., \& Létolle, R. (1987). Hydrogen and carbon isotope fractionation during experimental production of bacterial methane. Organic Geochemistry, 11(2), 115-119. https://doi.org/10.1016/0146-6380(87)90033-7

Bekker, A., Holmden, C., Beukes, N. J., Kenig, F., Eglinton, B., \& Patterson, W. P. (2008). Fractionation between inorganic and organic carbon during the Lomagundi $(2.22-2.1 \mathrm{Ga})$ carbon isotope excursion. Earth and Planetary Science Letters, 271(1), 278-291. https://doi.org/10.1016/j.eps1.2008.04.021

Blair, N., Leu, A., Muñoz, E., Olsen, J., Kwong, E., \& Marais, D. D. (1985). Carbon isotopic fractionation in heterotrophic microbial metabolism. Applied and Environmental Microbiology, 50(4), 996-1001.

Bol, R., Henson, S. A., Rumyantseva, A., \& Briggs, N. (2018). High-Frequency Variability of Small-Particle Carbon Export Flux in the Northeast Atlantic. Global Biogeochemical Cycles, 32(12), 1803-1814. https://doi.org/10.1029/2018GB005963

Breitburg, D., Levin, L. A., Oschlies, A., Grégoire, M., Chavez, F. P., Conley, D. J., et al. (2018). Declining oxygen in the global ocean and coastal waters. Science, 359(6371), eaam7240. https://doi.org/10.1126/science.aam7240

van Breugel, Y., Schouten, S., Paetzel, M., Nordeide, R., \& Sinninghe Damsté, J. S. (2005a). The impact of recycling of organic carbon on the stable carbon isotopic composition of dissolved inorganic carbon in a stratified marine system (Kyllaren fjord, Norway). Organic Geochemistry, 36(8), 1163-1173. https://doi.org/10.1016/j.orggeochem.2005.03.003 
This is a non-peer reviewed preprint: version 2 of a manuscript submitted to Global Biogeochemical Cycles, which has been modified according to reviewers' comments and is currently in review again at Global Biogeochemical Cycles.

van Breugel, Y., Schouten, S., Paetzel, M., Ossebaar, J., \& Sinninghe Damsté, J. S. (2005b). Reconstruction of $\delta^{13} \mathrm{C}$ of chemocline $\mathrm{CO}^{2}(\mathrm{aq})$ in past oceans and lakes using the $\delta^{13} \mathrm{C}$ of fossil isorenieratene. Earth and Planetary Science Letters, 235(1), 421-434. https://doi.org/10.1016/j.eps1.2005.04.017

Buesseler, K. O., Antia, A. N., Chen, M., Fowler, S. W., Gardner, W. D., Gustafsson, O., et al. (2007). An assessment of the use of sediment traps for estimating upper ocean particle fluxes. Journal of Marine Research, 65(3), 345-416. https://doi.org/10.1357/002224007781567621

Burd, A. B., \& Jackson, G. A. (2009). Particle Aggregation. Annual Review of Marine Science, 1(1), 65-90. https://doi.org/10.1146/annurev.marine.010908.163904 Burdige, D. J. (2007). Preservation of Organic Matter in Marine Sediments: Controls, Mechanisms, and an Imbalance in Sediment Organic Carbon Budgets? Chemical Reviews, 107(2), 467-485.

https://doi.org/10.1021/cr050347q

Cabré, A., Marinov, I., Bernardello, R., \& Bianchi, D. (2015). Oxygen minimum zones in the tropical Pacific across CMIP5 models: mean state differences and climate change trends. Biogeosciences, 12(18), 5429-5454. https://doi.org/10.5194/bg-12-5429-2015

Canfield, D. E. (2006). Models of oxic respiration, denitrification and sulfate reduction in zones of coastal upwelling. Geochimica et Cosmochimica Acta, 70(23), 5753-5765. https://doi.org/10.1016/j.gca.2006.07.023

Close, H. G. (2019). Compound-Specific Isotope Geochemistry in the Ocean. Annual Review of Marine Science, 11(1), 27-56. https://doi.org/10.1146/annurev-marine-121916-063634

Cooke, M. P., Talbot, H. M., \& Farrimond, P. (2008). Bacterial populations recorded in bacteriohopanepolyol distributions in soils from Northern England. Organic Geochemistry, 39(9), 1347-1358. https://doi.org/10.1016/j.orggeochem.2008.05.003

Cooke, M. P., van Dongen, B. E., Talbot, H. M., Semiletov, I., Shakhova, N., Guo, L., \& Gustafsson, Ö. (2009). Bacteriohopanepolyol biomarker composition of organic matter exported to the Arctic Ocean by seven of the major Arctic rivers. Organic Geochemistry, 40(11), 11511159. https://doi.org/10.1016/j.orggeochem.2009.07.014

Cowie, G. (2005). The biogeochemistry of Arabian Sea surficial sediments: A review of recent studies. Progress in Oceanography, 65(2), 260-289.

https://doi.org/10.1016/j.pocean.2005.03.003

Cowie, G. L., \& Hedges, J. I. (1992). Sources and reactivities of amino acids in a coastal marine environment. Limnology and Oceanography, 37(4), 703-724.

https://doi.org/10.4319/1o.1992.37.4.0703

Cowie, G. L., Calvert, S. E., Pedersen, T. F., Schulz, H., \& von Rad, U. (1999). Organic content and preservational controls in surficial shelf and slope sediments from the Arabian Sea (Pakistan margin). Marine Geology, 161(1), 23-38. https://doi.org/10.1016/S0025-3227(99)00053-5 
This is a non-peer reviewed preprint: version 2 of a manuscript submitted to Global Biogeochemical Cycles, which has been modified according to reviewers' comments and is currently in review again at Global Biogeochemical Cycles.

Cowie, G. L., Mowbray, S., Lewis, M., Matheson, H., \& McKenzie, R. (2009). Carbon and nitrogen elemental and stable isotopic compositions of surficial sediments from the Pakistan margin of the Arabian Sea. Deep Sea Research Part II: Topical Studies in Oceanography, 56(6), 271-282. https://doi.org/10.1016/j.dsr2.2008.05.031

Dalsgaard, T., Stewart, F. J., Thamdrup, B., Brabandere, L. D., Revsbech, N. P., Ulloa, O., et al. (2014). Oxygen at Nanomolar Levels Reversibly Suppresses Process Rates and Gene Expression in Anammox and Denitrification in the Oxygen Minimum Zone off Northern Chile. MBio, 5(6), e01966-14. https://doi.org/10.1128/mBio.01966-14

Devol, A. H. (2015). Denitrification, Anammox, and $\mathrm{N}_{2}$ Production in Marine Sediments. Annual Review of Marine Science, 7(1), 403-423. https://doi.org/10.1146/annurev-marine010213-135040

Dunne, J. P., Sarmiento, J. L., \& Gnanadesikan, A. (2007). A synthesis of global particle export from the surface ocean and cycling through the ocean interior and on the seafloor. Global Biogeochemical Cycles, 21(4). https://doi.org/10.1029/2006GB002907

Fernandes, S., Mazumdar, A., Bhattacharya, S., Peketi, A., Mapder, T., Roy, R., et al. (2018). Enhanced carbon-sulfur cycling in the sediments of Arabian Sea oxygen minimum zone center. Scientific Reports, 8(1), 8665. https://doi.org/10.1038/s41598-018-27002-2

Fischer, W. W., Summons, R. E., \& Pearson, A. (2005). Targeted genomic detection of biosynthetic pathways: anaerobic production of hopanoid biomarkers by a common sedimentary microbe. Geobiology, 3(1), 33-40. https://doi.org/10.1111/j.1472-4669.2005.00041.x

Fontugne, M., \& Duplessy, J. C. (1978). Carbon isotope ratio of marine plankton related to surface water masses. Earth and Planetary Science Letters, 41(3), 365-371. https://doi.org/10.1016/0012-821X(78)90191-7

Fontugne, M. R., \& Duplessy, J.-C. (1986). Variations of the monsoon regime during the upper quaternary: Evidence from carbon isotopic record of organic matter in North Indian Ocean sediment cores. Palaeogeography, Palaeoclimatology, Palaeoecology, 56(1), 69-88. https://doi.org/10.1016/0031-0182(86)90108-2

Freeman, K. H. (2001). Isotopic Biogeochemistry of Marine Organic Carbon. Reviews in Mineralogy and Geochemistry, 43(1), 579-605. https://doi.org/10.2138/gsrmg.43.1.579

Freeman, K. H., Wakeham, S. G., \& Hayes, J. M. (1994). Predictive isotopic biogeochemistry: Hydrocarbons from anoxic marine basins. Organic Geochemistry, 21(6), 629-644. https://doi.org/10.1016/0146-6380(94)90009-4

Fry, B., Jannasch, H. W., Molyneaux, S. J., Wirsen, C. O., Muramoto, J. A., \& King, S. (1991). Stable isotope studies of the carbon, nitrogen and sulfur cycles in the Black Sea and the Cariaco Trench. Deep Sea Research Part A. Oceanographic Research Papers, 38, S1003-S1019. https://doi.org/10.1016/S0198-0149(10)80021-4 
This is a non-peer reviewed preprint: version 2 of a manuscript submitted to Global Biogeochemical Cycles, which has been modified according to reviewers' comments and is currently in review again at Global Biogeochemical Cycles.

Galimov, E. M. (1988). Sources and mechanisms of formation of gaseous hydrocarbons in sedimentary rocks. Chemical Geology, 71(1), 77-95. https://doi.org/10.1016/00092541(88)90107-6

Gong, C., \& Hollander, D. J. (1997). Differential contribution of bacteria to sedimentary organic matter in oxic and anoxic environments, Santa Monica Basin, California. Organic Geochemistry, 26(9), 545-563. https://doi.org/10.1016/S0146-6380(97)00018-1

Härtner, T., Straub, K. L., \& Kannenberg, E. (2005). Occurrence of hopanoid lipids in anaerobic Geobacter species. FEMS Microbiology Letters, 243(1), 59-64.

https://doi.org/10.1016/j.femsle.2004.11.039

Hartnett, H. E., Keil, R. G., Hedges, J. I., \& Devol, A. H. (1998). Influence of oxygen exposure time on organic carbon preservation in continental margin sediments. Nature, 391(6667), 572575. https://doi.org/10.1038/35351

Hatch, J. R., \& Leventhal, J. S. (1997). Early diagenetic partial oxidation of organic matter and sulfides in the Middle Pennsylvanian (Desmoinesian) Excello Shale member of the Fort Scott Limestone and equivalents, northern Midcontinent region, USA. Chemical Geology, 134(4), 215-235. https://doi.org/10.1016/S0009-2541(96)00006-X

Hayes, J. M. (2001). Fractionation of Carbon and Hydrogen Isotopes in Biosynthetic Processes. Reviews in Mineralogy and Geochemistry, 43(1), 225-277. https://doi.org/10.2138/gsrmg.43.1.225

Hedges, J. I., \& Keil, R. G. (1995). Sedimentary organic matter preservation: an assessment and speculative synthesis. Marine Chemistry, 49(2), 81-115. https://doi.org/10.1016/03044203(95)00008-F

Helly, J. J., \& Levin, L. A. (2004). Global distribution of naturally occurring marine hypoxia on continental margins. Deep Sea Research Part I: Oceanographic Research Papers, 51(9), 11591168. https://doi.org/10.1016/j.dsr.2004.03.009Herndl, G. J., \& Reinthaler, T. (2013). Microbial control of the dark end of the biological pump. Nature Geoscience, 6(9), 718-724. https://doi.org/10.1038/ngeo1921

Hollander, D. J., \& Smith, M. A. (2001). Microbially mediated carbon cycling as a control on the $\delta^{13} \mathrm{C}$ of sedimentary carbon in eutrophic Lake Mendota (USA): new models for interpreting isotopic excursions in the sedimentary record. Geochimica et Cosmochimica Acta, 65(23), 43214337. https://doi.org/10.1016/S0016-7037(00)00506-8

Huguet, C., de Lange, G. J., Gustafsson, Ö., Middelburg, J. J., Sinninghe Damsté, J. S., \& Schouten, S. (2008). Selective preservation of soil organic matter in oxidized marine sediments (Madeira Abyssal Plain). Geochimica et Cosmochimica Acta, 72(24), 6061-6068. https://doi.org/10.1016/j.gca.2008.09.021 
This is a non-peer reviewed preprint: version 2 of a manuscript submitted to Global Biogeochemical Cycles, which has been modified according to reviewers' comments and is currently in review again at Global Biogeochemical Cycles.

Jaeschke, A., Ziegler, M., Hopmans, E. C., Reichart, G.-J., Lourens, L. J., Schouten, S., \& Sinninghe Damsté, J. S. (2009). Molecular fossil evidence for anaerobic ammonium oxidation in the Arabian Sea over the last glacial cycle: Anammox in the Arabian Sea. Paleoceanography, 24(2), n/a-n/a. https://doi.org/10.1029/2008PA001712

Jeffrey, A. W. A., Pflaum, R. C., Brooks, J. M., \& Sackett, W. M. (1983). Vertical trends in particulate organic carbon ${ }^{13} \mathrm{C}:{ }^{12} \mathrm{C}$ ratios in the upper water column. Deep Sea Research Part A. Oceanographic Research Papers, 30(9), 971-983. https://doi.org/10.1016/0198-0149(83)900523

Jenkyns, H. C. (1985). The early Toarcian and Cenomanian-Turonian anoxic events in Europe: comparisons and contrasts. Geologische Rundschau, 74(3), 505-518.

https://doi.org/10.1007/BF01821208

Jenkyns, H. C. (2010). Geochemistry of oceanic anoxic events: REVIEW. Geochemistry, Geophysics, Geosystems, 11(3). https://doi.org/10.1029/2009GC002788

Jensen, M. M., Lam, P., Revsbech, N. P., Nagel, B., Gaye, B., Jetten, M. S., \& Kuypers, M. M. (2011). Intensive nitrogen loss over the Omani Shelf due to anammox coupled with dissimilatory nitrite reduction to ammonium. The ISME Journal, 5(10), 1660-1670.

https://doi.org/10.1038/ismej.2011.44

Jetten, M. S. M., Wagner, M., Fuerst, J., van Loosdrecht, M., Kuenen, G., \& Strous, M. (2001). Microbiology and application of the anaerobic ammonium oxidation ('anammox') process. Current Opinion in Biotechnology, 12(3), 283-288. https://doi.org/10.1016/S09581669(00)00211-1

Keil, R. G., Neibauer, J. A., Biladeau, C., van der Elst, K., \& Devol, A. H. (2016). A multiproxy approach to understanding the "enhanced" flux of organic matter through the oxygen-deficient waters of the Arabian Sea. Biogeosciences, 13(7), 2077-2092. https://doi.org/10.5194/bg-132077-2016

Keil, Richard G., Montluçon, D. B., Prahl, F. G., \& Hedges, J. I. (1994). Sorptive preservation of labile organic matter in marine sediments. Nature, 370(6490), 549-552. https://doi.org/10.1038/370549a0

Kharbush, J. J., Thompson, L. R., Haroon, M. F., Knight, R., \& Aluwihare, L. I. (2018). Hopanoid-producing bacteria in the Red Sea include the major marine nitrite oxidizers. FEMS Microbiology Ecology, 94(6). https://doi.org/10.1093/femsec/fiy063

Koho, K. A., Nierop, K. G. J., Moodley, L., Middelburg, J. J., Pozzato, L., Soetaert, K., et al. (2013). Microbial bioavailability regulates organic matter preservation in marine sediments. Biogeosciences, 10(2), 1131-1141. https://doi.org/10.5194/bg-10-1131-2013 
This is a non-peer reviewed preprint: version 2 of a manuscript submitted to Global Biogeochemical Cycles, which has been modified according to reviewers' comments and is currently in review again at Global Biogeochemical Cycles.

Könneke, M., Lipp, J. S., \& Hinrichs, K.-U. (2012). Carbon isotope fractionation by the marine ammonia-oxidizing archaeon Nitrosopumilus maritimus. Organic Geochemistry, 48, 21-24. https://doi.org/10.1016/j.orggeochem.2012.04.007

Köster, J., Rospondek, M., Schouten, S., Kotarba, M., Zubrzycki, A., \& Sinninghe Damste, J. S. (1998). Biomarker geochemistry of a foreland basin: the Oligocene Menilite Formation in the Flysch Carpathians of Southeast Poland. Organic Geochemistry, 29(1), 649-669. https://doi.org/10.1016/S0146-6380(98)00182-X

Kroopnick, P. M. (1985). The distribution of ${ }^{13} \mathrm{C}$ of $\Sigma \mathrm{CO}_{2}$ in the world oceans. Deep Sea Research Part A. Oceanographic Research Papers, 32(1), 57-84. https://doi.org/10.1016/01980149(85)90017-2

Kuypers, M. M. M., Sliekers, A. O., Lavik, G., Schmid, M., Jørgensen, B. B., Kuenen, J. G., et al. (2003). Anaerobic ammonium oxidation by anammox bacteria in the Black Sea. Nature, 422(6932), 608-611. https://doi.org/10.1038/nature01472

Kuypers, Marcel M. M., Pancost, Richard D., Nijenhuis, Ivar A., \& Sinninghe Damsté, Jaap S. (2002). Enhanced productivity led to increased organic carbon burial in the euxinic North Atlantic basin during the late Cenomanian oceanic anoxic event. Paleoceanography, 17(4), 3-1. https://doi.org/10.1029/2000PA000569

Lam, P., Lavik, G., Jensen, M. M., van de Vossenberg, J., Schmid, M., Woebken, D., et al. (2009). Revising the nitrogen cycle in the Peruvian oxygen minimum zone. Proceedings of the National Academy of Sciences, 106(12), 4752-4757. https://doi.org/10.1073/pnas.0812444106

Lam, Phyllis, \& Kuypers, M. M. M. (2010). Microbial Nitrogen Cycling Processes in Oxygen Minimum Zones. Annual Review of Marine Science, 3(1), 317-345. https://doi.org/10.1146/annurev-marine-120709-142814

Lam, Phyllis, Jensen, M. M., Lavik, G., McGinnis, D. F., Müller, B., Schubert, C. J., et al. (2007). Linking crenarchaeal and bacterial nitrification to anammox in the Black Sea. Proceedings of the National Academy of Sciences, 104(17), 7104-7109. https://doi.org/10.1073/pnas.0611081104

Leckie, R. M., Bralower, T. J., \& Cashman, R. (2002). Oceanic anoxic events and plankton evolution: Biotic response to tectonic forcing during the mid-Cretaceous. Paleoceanography, 17(3), 13-1-13-29. https://doi.org/10.1029/2001PA000623

Lengger, S. K., Hopmans, E. C., Sinninghe Damsté, J. S., \& Schouten, S. (2012a). Comparison of extraction and work up techniques for analysis of core and intact polar tetraether lipids from sedimentary environments. Organic Geochemistry, 47, 34-40. https://doi.org/10.1016/j.orggeochem.2012.02.009

Lengger, S. K., Hopmans, E. C., Reichart, G.-J., Nierop, K. G. J., Sinninghe Damsté, J. S., \& Schouten, S. (2012b). Intact polar and core glycerol dibiphytanyl glycerol tetraether lipids in the 
This is a non-peer reviewed preprint: version 2 of a manuscript submitted to Global Biogeochemical Cycles, which has been modified according to reviewers' comments and is currently in review again at Global Biogeochemical Cycles.

Arabian Sea oxygen minimum zone. Part II: Selective preservation and degradation in sediments and consequences for the TEX ${ }_{86}$. Geochimica et Cosmochimica Acta, 98, 244-258. https://doi.org/10.1016/j.gca.2012.05.003

Lengger, S. K., Hopmans, E. C., Sinninghe Damsté, J. S., \& Schouten, S. (2014). Impact of sedimentary degradation and deep water column production on GDGT abundance and distribution in surface sediments in the Arabian Sea: Implications for the TEX 86 paleothermometer. Geochimica et Cosmochimica Acta, 142, 386-399. https://doi.org/10.1016/j.gca.2014.07.013

Lengger, S. K., Sutton, P. A., Rowland, S. J., Hurley, S. J., Pearson, A., Naafs, B. D. A., et al. (2018). Archaeal and bacterial glycerol dialkyl glycerol tetraether (GDGT) lipids in environmental samples by high temperature-gas chromatography with flame ionization and timeof-flight mass spectrometry detection. Organic Geochemistry, 121, 10-21.

https://doi.org/10.1016/j.orggeochem.2018.03.012

Liu, K.-K., Kao, S.-J., Hu, H.-C., Chou, W.-C., Hung, G.-W., \& Tseng, C.-M. (2007). Carbon isotopic composition of suspended and sinking particulate organic matter in the northern South China Sea-From production to deposition. Deep Sea Research Part II: Topical Studies in Oceanography, 54(14), 1504-1527. https://doi.org/10.1016/j.dsr2.2007.05.010

Lüke, C., Speth, D. R., Kox, M. A. R., Villanueva, L., \& Jetten, M. S. M. (2016). Metagenomic analysis of nitrogen and methane cycling in the Arabian Sea oxygen minimum zone. PeerJ, 4, e1924. https://doi.org/10.7717/peerj.1924

Luo, G., Algeo, T. J., Huang, J., Zhou, W., Wang, Y., Yang, H., et al. (2014). Vertical $\delta^{13}$ Corg gradients record changes in planktonic microbial community composition during the endPermian mass extinction. Palaeogeography, Palaeoclimatology, Palaeoecology, 396, 119-131. https://doi.org/10.1016/j.palaeo.2014.01.006

Matys, E. D., Sepúlveda, J., Pantoja, S., Lange, C. B., Caniupán, M., Lamy, F., \& Summons, R. E. (2017). Bacteriohopanepolyols along redox gradients in the Humboldt Current System off northern Chile. Geobiology, 15(6), 844-857. https://doi.org/10.1111/gbi.12250

Meyers, P. A. (2014). Why are the $\delta^{13} \mathrm{C}$ org values in Phanerozoic black shales more negative than in modern marine organic matter? Geochemistry, Geophysics, Geosystems, 15(7), 30853106. https://doi.org/10.1002/2014GC005305

Meyers, P. A., \& Arnaboldi, M. (2008). Paleoceanographic implications of nitrogen and organic carbon isotopic excursions in mid-Pleistocene sapropels from the Tyrrhenian and Levantine Basins, Mediterranean Sea. Palaeogeography, Palaeoclimatology, Palaeoecology, 266(1), 112 118. https://doi.org/10.1016/j.palaeo.2008.03.018

Middelburg, J. J. (1989). A simple rate model for organic matter decomposition in marine sediments. Geochimica et Cosmochimica Acta, 53(7), 1577-1581. https://doi.org/10.1016/00167037(89)90239-1 
This is a non-peer reviewed preprint: version 2 of a manuscript submitted to Global Biogeochemical Cycles, which has been modified according to reviewers' comments and is currently in review again at Global Biogeochemical Cycles.

Middelburg, J. J., Vlug, T., Jaco, F., \& van der Nat, W. A. (1993). Organic matter mineralization in marine systems. Global and Planetary Change, 8(1), 47-58. https://doi.org/10.1016/09218181(93)90062-S

Middelburg J. J. (2011). Chemoautotrophy in the ocean. Geophysical Research Letters, 38(24). https://doi.org/10.1029/2011GL049725

Moos, C. (2000). Reconstruction of upwelling intensity and paleo-nutrient gradients in the Northwest Arabian Sea derived from stable carbon and oxygen isotopes of planktic foraminifera. University of Bremen, Bremen, Germany. Retrieved from http://elib.suub.unibremen.de/ip/docs/00010276.pdf

Naqvi, S. W. A., \& Shailaja, M. S. (1993). Activity of the respiratory electron transport system and respiration rates within the oxygen minimum layer of the Arabian Sea. Deep Sea Research Part II: Topical Studies in Oceanography, 40(3), 687-695. https://doi.org/10.1016/09670645(93)90052-O

Nierop, K. G. J., Reichart, G.-J., Veld, H., \& Sinninghe Damsté, J. S. (2017). The influence of oxygen exposure time on the composition of macromolecular organic matter as revealed by surface sediments on the Murray Ridge (Arabian Sea). Geochimica et Cosmochimica Acta, 206, 40-56. https://doi.org/10.1016/j.gca.2017.02.032

Pachiadaki, M. G., Sintes, E., Bergauer, K., Brown, J. M., Record, N. R., Swan, B. K., et al. (2017). Major role of nitrite-oxidizing bacteria in dark ocean carbon fixation. Science, 358(6366), 1046-1051. https://doi.org/10.1126/science.aan8260

Pagani, M. (2005). Marked Decline in Atmospheric Carbon Dioxide Concentrations During the Paleogene. Science, 309(5734), 600-603. https://doi.org/10.1126/science.1110063

Pancost, R. D., \& Pagani, M. (2005). Controls on the Carbon Isotopic Compositions of Lipids in Marine Environments. In Marine Organic Matter: Biomarkers, Isotopes and DNA (pp. 209249). Springer, Berlin, Heidelberg. https://doi.org/10.1007/698_2_007

Pancost, R. D., \& Sinninghe Damsté, J. S. (2003). Carbon isotopic compositions of prokaryotic lipids as tracers of carbon cycling in diverse settings. Chemical Geology, 195(1-4), 29-58. https://doi.org/10.1016/S0009-2541(02)00387-X

Pancost, R. D., Freeman, K. H., \& Patzkowsky, M. E. (1999). Organic-matter source variation and the expression of a late Middle Ordovician carbon isotope excursion. Geology, 27(11), 1015-1018. https://doi.org/10.1130/0091-7613(1999)027<1015:OMSVAT>2.3.CO;2

Pancost, R. D., Steart, D. S., Handley, L., Collinson, M. E., Hooker, J. J., Scott, A. C., et al. (2007). Increased terrestrial methane cycling at the Palaeocene-Eocene thermal maximum. Nature, 449(7160), 332-335. https://doi.org/10.1038/nature06012 
This is a non-peer reviewed preprint: version 2 of a manuscript submitted to Global Biogeochemical Cycles, which has been modified according to reviewers' comments and is currently in review again at Global Biogeochemical Cycles.

Pancost, R. D., Freeman, K. H., Herrmann, A. D., Patzkowsky, M. E., Ainsaar, L., \& Martma, T. (2013). Reconstructing Late Ordovician carbon cycle variations. Geochimica et Cosmochimica Acta, 105, 433-454. https://doi.org/10.1016/j.gca.2012.11.033

Parnell, A. C., Inger, R., Bearhop, S., \& Jackson, A. L. (2010). Source Partitioning Using Stable Isotopes: Coping with Too Much Variation. PLOS ONE, 5(3), e9672.

https://doi.org/10.1371/journal.pone.0009672

Paulmier, A., \& Ruiz-Pino, D. (2009). Oxygen minimum zones (OMZs) in the modern ocean. Progress in Oceanography, 80(3-4), 113-128. https://doi.org/10.1016/j.pocean.2008.08.001

Pearson, A. (2010). Pathways of Carbon Assimilation and Their Impact on Organic Matter Values $\delta 13 C$. In K. N. Timmis (Ed.), Handbook of Hydrocarbon and Lipid Microbiology (pp. 143-156). Berlin, Heidelberg: Springer Berlin Heidelberg. Retrieved from http://link.springer.com/10.1007/978-3-540-77587-4_9

Pearson, Ann, \& Rusch, D. B. (2009). Distribution of microbial terpenoid lipid cyclases in the global ocean metagenome. The ISME Journal, 3(3), 352-363. https://doi.org/10.1038/ismej.2008.116

Phillips, D. L., Newsome, S. D., \& Gregg, J. W. (2005). Combining sources in stable isotope mixing models: alternative methods. Oecologia, 144(4), 520-527.

https://doi.org/10.1007/s00442-004-1816-8

Pitcher, A., Villanueva, L., Hopmans, E. C., Schouten, S., Reichart, G.-J., \& Sinninghe Damsté, J. S. (2011). Niche segregation of ammonia-oxidizing archaea and anammox bacteria in the Arabian Sea oxygen minimum zone. The ISME Journal, 5(12), 1896-1904. https://doi.org/10.1038/ismej.2011.60

Pozzato, L., Oevelen, D. V., Moodley, L., Soetaert, K., \& Middelburg, J. J. (2013a). Sink or link? The bacterial role in benthic carbon cycling in the Arabian Sea's oxygen minimum zone. Biogeosciences, 10(11), 6879-6891. https://doi.org/10.5194/bg-10-6879-2013

Pozzato, Lara, van Oevelen, D., Moodley, L., Soetaert, K., \& Middelburg, J. J. (2013b). Carbon processing at the deep-sea floor of the Arabian Sea oxygen minimum zone: A tracer approach. Journal of Sea Research, 78, 45-58. https://doi.org/10.1016/j.seares.2013.01.002

Queste, B. Y., Vic, C., Heywood, K. J., \& Piontkovski, S. A. (2018). Physical Controls on Oxygen Distribution and Denitrification Potential in the North West Arabian Sea. Geophysical Research Letters, 45(9), 4143-4152. https://doi.org/10.1029/2017GL076666

Reinthaler, T., van Aken, H. M., \& Herndl, G. J. (2010). Major contribution of autotrophy to microbial carbon cycling in the deep North Atlantic's interior. Deep Sea Research Part II: Topical Studies in Oceanography, 57(16), 1572-1580.

https://doi.org/10.1016/j.dsr2.2010.02.023 
This is a non-peer reviewed preprint: version 2 of a manuscript submitted to Global Biogeochemical Cycles, which has been modified according to reviewers' comments and is currently in review again at Global Biogeochemical Cycles.

1002

1003

1004

1005

1006

1007

1008

1009

1010

1011

1012

1013

1014

1015

1016

1017

1018

1019

1020

1021

1022

1023

1024

1025

1026

1027

1028

1029

1030

1031

1032

1033

1034

1035

1036

Rixen, T., \& Ittekkot, V. (2005). Nitrogen deficits in the Arabian Sea, implications from a three component mixing analysis. Deep Sea Research Part II: Topical Studies in Oceanography, 52(14-15), 1879-1891. https://doi.org/10.1016/j.dsr2.2005.06.007

Roullier, F., Berline, L., Guidi, L., Durrieu De Madron, X., Picheral, M., Sciandra, A., et al. (2014). Particle size distribution and estimated carbon flux across the Arabian Sea oxygen minimum zone. Biogeosciences, 11(16), 4541-4557. https://doi.org/10.5194/bg-11-4541-2014

Rush, D., \& Sinninghe Damsté, J. S. (2017). Lipids as paleomarkers to constrain the marine nitrogen cycle: Lipids as paleomarkers. Environmental Microbiology, 19(6), 2119-2132. https://doi.org/10.1111/1462-2920.13682

Rush, D., Sinninghe Damsté, J. S., Poulton, S. W., Thamdrup, B., Garside, A. L., Acuña González, J., et al. (2014). Anaerobic ammonium-oxidising bacteria: A biological source of the bacteriohopanetetrol stereoisomer in marine sediments. Geochimica et Cosmochimica Acta, 140, 50-64. https://doi.org/10.1016/j.gca.2014.05.014

Rush, D., Talbot, H. M., Meer, M. T. J. van der, Hopmans, E. C., Douglas, B., \& Sinninghe Damsté, J. S. (2019). Biomarker evidence for the occurrence of anaerobic ammonium oxidation in the eastern Mediterranean Sea during Quaternary and Pliocene sapropel formation. Biogeosciences Discussions, 1-27. https://doi.org/10.5194/bg-2019-27

Sáenz, J. P., Wakeham, S. G., Eglinton, T. I., \& Summons, R. E. (2011). New constraints on the provenance of hopanoids in the marine geologic record: Bacteriohopanepolyols in marine suboxic and anoxic environments. Organic Geochemistry, 42(11), 1351-1362. https://doi.org/10.1016/j.orggeochem.2011.08.016

Sakata, S., Hayes, J. M., McTaggart, A. R., Evans, R. A., Leckrone, K. J., \& Togasaki, R. K. (1997). Carbon isotopic fractionation associated with lipid biosynthesis by a cyanobacterium: Relevance for interpretation of biomarker records. Geochimica et Cosmochimica Acta, 61(24), 5379-5389. https://doi.org/10.1016/S0016-7037(97)00314-1

Schenau, S. J., Passier, H. F., Reichart, G. J., \& de Lange, G. J. (2002). Sedimentary pyrite formation in the Arabian Sea. Marine Geology, 185(3), 393-402. https://doi.org/10.1016/S00253227(02)00183-4

Schlitzer, R. (2002). Carbon export fluxes in the Southern Ocean: results from inverse modeling and comparison with satellite-based estimates. Deep Sea Research Part II: Topical Studies in Oceanography, 49(9), 1623-1644. https://doi.org/10.1016/S0967-0645(02)00004-8

Schmaljohann, R., Drews, M., Walter, S., Linke, P., Rad, U. von, \& Imhoff, J. F. (2001). Oxygen-minimum zone sediments in the northeastern Arabian Sea off Pakistan: a habitat for the bacterium Thioploca. Marine Ecology Progress Series, 211, 27-42.

https://doi.org/10.3354/meps211027 
This is a non-peer reviewed preprint: version 2 of a manuscript submitted to Global Biogeochemical Cycles, which has been modified according to reviewers' comments and is currently in review again at Global Biogeochemical Cycles.

Schmidtko, S., Stramma, L., \& Visbeck, M. (2017). Decline in global oceanic oxygen content during the past five decades. Nature, 542(7641), 335-339. https://doi.org/10.1038/nature21399

Schouten, S., Strous, M., Kuypers, M. M. M., Rijpstra, W. I. C., Baas, M., Schubert, C. J., et al. (2004). Stable Carbon Isotopic Fractionations Associated with Inorganic Carbon Fixation by Anaerobic Ammonium-Oxidizing Bacteria. Applied and Environmental Microbiology, 70(6), 3785-3788. https://doi.org/10.1128/AEM.70.6.3785-3788.2004

Schouten, Stefan, Klein Breteler, W. C. M., Blokker, P., Schogt, N., Rijpstra, W. I. C., Grice, K., et al. (1998). Biosynthetic effects on the stable carbon isotopic compositions of algal lipids: implications for deciphering the carbon isotopic biomarker record. Geochimica et Cosmochimica Acta, 62(8), 1397-1406. https://doi.org/10.1016/S0016-7037(98)00076-3

Schouten, Stefan, Hoefs, M. J. L., \& Sinninghe Damsté, J. S. (2000). A molecular and stable carbon isotopic study of lipids in late Quaternary sediments from the Arabian Sea. Organic Geochemistry, 31(6), 509-521. https://doi.org/10.1016/S0146-6380(00)00031-0

Schouten, Stefan, Pitcher, A., Hopmans, E. C., Villanueva, L., van Bleijswijk, J., \& Sinninghe Damsté, J. S. (2012). Intact polar and core glycerol dibiphytanyl glycerol tetraether lipids in the Arabian Sea oxygen minimum zone: I. Selective preservation and degradation in the water column and consequences for the TEX86. Geochimica et Cosmochimica Acta, 98, 228-243. https://doi.org/10.1016/j.gca.2012.05.002

Sessions, A. L., Zhang, L., Welander, P. V., Doughty, D., Summons, R. E., \& Newman, D. K. (2013). Identification and quantification of polyfunctionalized hopanoids by high temperature gas chromatography-mass spectrometry. Organic Geochemistry, 56, 120-130. https://doi.org/10.1016/j.orggeochem.2012.12.009

Shaffer, G., Olsen, S. M., \& Pedersen, J. O. P. (2009). Long-term ocean oxygen depletion in response to carbon dioxide emissions from fossil fuels. Nature Geoscience, 2(2), 105-109. https://doi.org/10.1038/ngeo420

Sokoll, S., Holtappels, M., Lam, P., Collins, G., Schlüter, M., Lavik, G., \& Kuypers, M. M. M. (2012). Benthic Nitrogen Loss in the Arabian Sea Off Pakistan. Frontiers in Microbiology, 3. https://doi.org/10.3389/fmicb.2012.00395

Spiker, E. C., \& Hatcher, P. G. (1987). The effects of early diagenesis on the chemical and stable carbon isotopic composition of wood. Geochimica et Cosmochimica Acta, 51(6), 1385-1391. https://doi.org/10.1016/0016-7037(87)90323-1

Stramma, L., Schmidtko, S., Levin, L. A., \& Johnson, G. C. (2010). Ocean oxygen minima expansions and their biological impacts. Deep Sea Research Part I: Oceanographic Research Papers, 57(4), 587-595. https://doi.org/10.1016/j.dsr.2010.01.005

Strous, M., Kuenen, J. G., \& Jetten, M. S. M. (1999). Key Physiology of Anaerobic Ammonium Oxidation. Applied and Environmental Microbiology, 65(7), 3248-3250. 
This is a non-peer reviewed preprint: version 2 of a manuscript submitted to Global Biogeochemical Cycles, which has been modified according to reviewers' comments and is currently in review again at Global Biogeochemical Cycles.

Talbot, H. M., Rohmer, M., \& Farrimond, P. (2007). Rapid structural elucidation of composite bacterial hopanoids by atmospheric pressure chemical ionization liquid chromatography/ion trap mass spectrometry. Rapid Communications in Mass Spectrometry, 21(6), 880-892. https://doi.org/10.1002/rcm.2911

Taylor, G. T., Iabichella, M., Ho, T.-Y., Scranton, M. I., Thunell, R. C., Muller-Karger, F., \& Varela, R. (2001). Chemoautotrophy in the redox transition zone of the Cariaco Basin: A significant midwater source of organic carbon production. Limnology and Oceanography, 46(1), 148-163. https://doi.org/10.4319/lo.2001.46.1.0148

Ulloa, O., Canfield, D. E., DeLong, E. F., Letelier, R. M., \& Stewart, F. J. (2012). Microbial oceanography of anoxic oxygen minimum zones. Proceedings of the National Academy of Sciences of the United States of America, 109(40), 15996-16003.

https://doi.org/10.1073/pnas.1205009109

Van Kaam-Peters, H. M. E., Schouten, S., Köster, J., \& Sinninghe Damstè, J. S. (1998). Controls on the molecular and carbon isotopic composition of organic matter deposited in a Kimmeridgian euxinic shelf sea: evidence for preservation of carbohydrates through sulfurization. Geochimica et Cosmochimica Acta, 62(19), 3259-3283. https://doi.org/10.1016/S0016-7037(98)00231-2

Villanueva, L., Speth, D. R., Vanalen, T., Hoischen, A., \& Jetten, M. (2014). Shotgun metagenomic data reveals significant abundance but low diversity of "Candidatus Scalindua" marine anammox bacteria in the Arabian Sea oxygen minimum zone. Frontiers in Microbiology, 5. https://doi.org/10.3389/fmicb.2014.00031

van de Vossenberg, J., Rattray, J. E., Geerts, W., Kartal, B., Niftrik, L. V., Donselaar, E. G. V., et al. (2008). Enrichment and characterization of marine anammox bacteria associated with global nitrogen gas production. Environmental Microbiology, 10(11), 3120-3129. https://doi.org/10.1111/j.1462-2920.2008.01643.x

van de Vossenberg, J., Woebken, D., Maalcke, W. J., Wessels, H. J. C. T., Dutilh, B. E., Kartal, B., et al. (2013). The metagenome of the marine anammox bacterium 'Candidatus Scalindua profunda' illustrates the versatility of this globally important nitrogen cycle bacterium. Environmental Microbiology, 15(5), 1275-1289. https://doi.org/10.1111/j.14622920.2012.02774.x

Wakeham, S. G., \& McNichol, A. P. (2014). Transfer of organic carbon through marine water columns to sediments - insights from stable and radiocarbon isotopes of lipid biomarkers. Biogeosciences, 11(23), 6895-6914. https://doi.org/10.5194/bg-11-6895-2014

Wakeham, Stuart G., Peterson, M. L., Hedges, J. I., \& Lee, C. (2002). Lipid biomarker fluxes in the Arabian Sea, with a comparison to the equatorial Pacific Ocean. Deep Sea Research Part II: Topical Studies in Oceanography, 49(12), 2265-2301. https://doi.org/10.1016/S09670645(02)00037-1 
This is a non-peer reviewed preprint: version 2 of a manuscript submitted to Global Biogeochemical Cycles, which has been modified according to reviewers' comments and is currently in review again at Global Biogeochemical Cycles.

Ward, B. B., Devol, A. H., Rich, J. J., Chang, B. X., Bulow, S. E., Naik, H., et al. (2009). Denitrification as the dominant nitrogen loss process in the Arabian Sea. Nature, 461(7260), 78 81. https://doi.org/10.1038/nature08276

van Winden, J. F., Talbot, H. M., Kip, N., Reichart, G.-J., Pol, A., McNamara, N. P., et al. (2012). Bacteriohopanepolyol signatures as markers for methanotrophic bacteria in peat moss. Geochimica et Cosmochimica Acta, 77, 52-61. https://doi.org/10.1016/j.gca.2011.10.026

Witkowski, C. R., Weijers, J. W. H., Blais, B., Schouten, S., \& Damsté, J. S. S. (2018). Molecular fossils from phytoplankton reveal secular $\mathrm{pCO}_{2}$ trend over the Phanerozoic. Science Advances, 4(11), eaat4556. https://doi.org/10.1126/sciadv.aat4556

Wright, J. J., Konwar, K. M., \& Hallam, S. J. (2012). Microbial ecology of expanding oxygen minimum zones. Nature Reviews Microbiology, 10(6), 381-394.

https://doi.org/10.1038/nrmicro2778

Wuchter, C. (2006). Archaeal nitrification in the ocean. Proceedings of the National Academy of Sciences, 103(33), 12317-12322. https://doi.org/10.1073/pnas.0600756103

Zachos, J. C., Röhl, U., Schellenberg, S. A., Sluijs, A., Hodell, D. A., Kelly, D. C., et al. (2005). Rapid Acidification of the Ocean During the Paleocene-Eocene Thermal Maximum. Science, 308(5728), 1611-1615. https://doi.org/10.1126/science.1109004

Zhang, C. L., Huang, Z., Cantu, J., Pancost, R. D., Brigmon, R. L., Lyons, T. W., \& Sassen, R. (2005). Lipid Biomarkers and Carbon Isotope Signatures of a Microbial (Beggiatoa) Mat Associated with Gas Hydrates in the Gulf of Mexico. Applied and Environmental Microbiology, 71(4), 2106-2112. https://doi.org/10.1128/AEM.71.4.2106-2112.2005

Ziegler, M., Jilbert, T., de Lange, G. J., Lourens, L. J., \& Reichart, G.-J. (2008). Bromine counts from XRF scanning as an estimate of the marine organic carbon content of sediment cores: Bromine as estimator for sediment composition. Geochemistry, Geophysics, Geosystems, 9(5). https://doi.org/10.1029/2007GC001932 
This is a non-peer reviewed preprint: version 2 of a manuscript submitted to Global Biogeochemical Cycles, which has been modified according to reviewers' comments and is currently in review again at Global Biogeochemical Cycles.

1147 Table 1. $\delta^{13} \mathrm{C}$ values of analysed samples. s.d. = standard deviation of three repeat analyses, n.d. $1148=$ not determined (single analysis). The values shown are natural abundance from unamended 1149 cores, and from incubations with ${ }^{13} \mathrm{C}$ labelled DOM and POM, under oxic and suboxic 1150 conditions. ${ }^{*}$ indicates outliers (Grubbs).

$\delta^{13} \mathrm{C}$ value [\%o V-PDB]

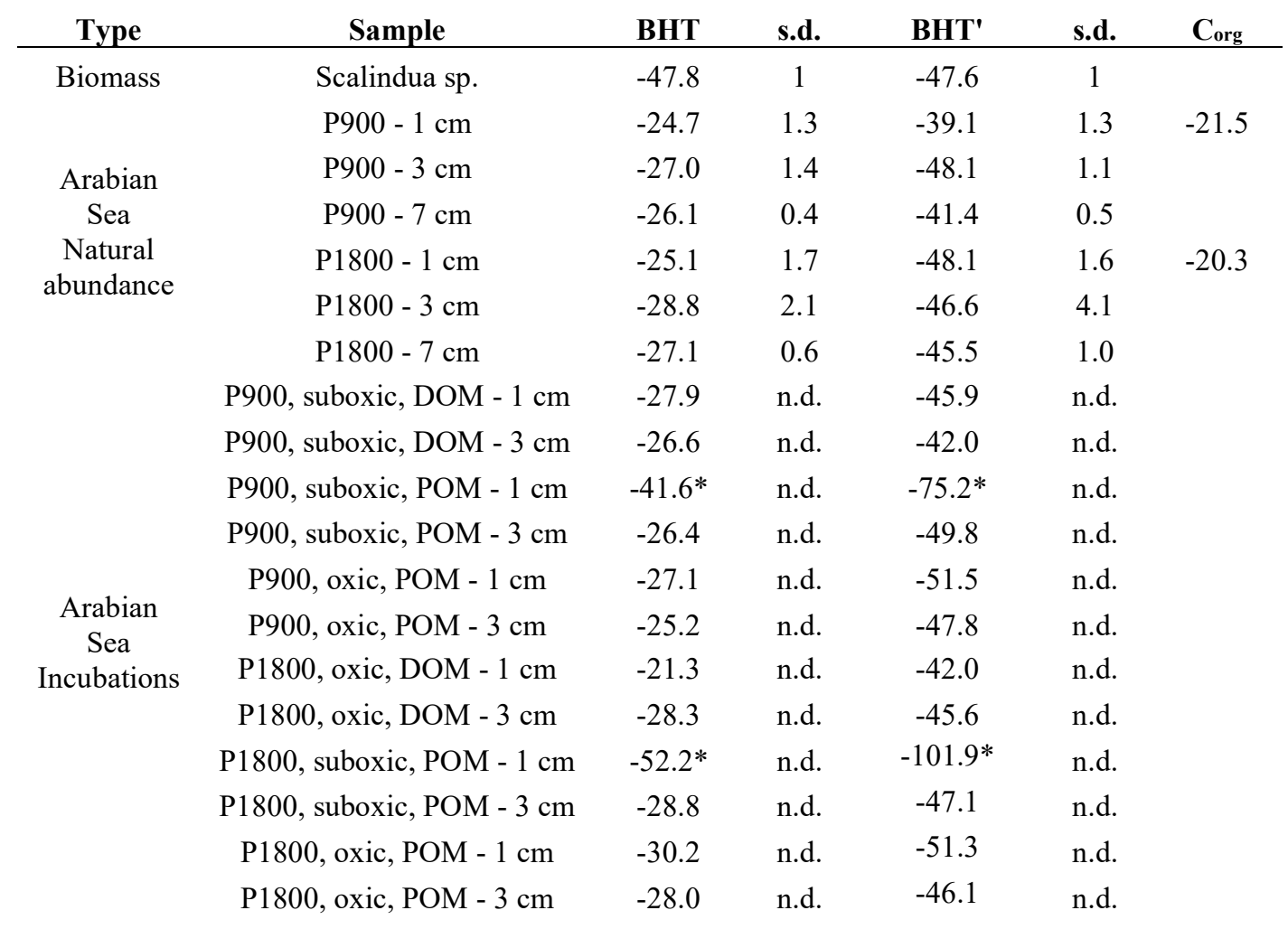

